\title{
Molecular aspects of calcium signalling at the crossroads of unikont and bikont eukaryote evolution - The ciliated protozoan Paramecium in focus
}

\author{
Helmut Plattner* \\ Department of Biology, University of Konstanz, P.O. Box M625, 78457 Konstanz, Germany
}

\section{A R T I C L E I N F O}

\section{Keywords:}

$\mathrm{Ca}^{2+}$

Calcium

Channel

Ciliate

Paramecium

Protozoa

\begin{abstract}
A B S T R A C T
The ciliated protozoan, Paramecium tetraurelia has a high basic $\mathrm{Ca}^{2+}$ leakage rate which is counteracted mainly by export through a contractile vacuole complex, based on its V-type $\mathrm{H}^{+}$-ATPase activity. In addition Paramecium cells dispose of P-type $\mathrm{Ca}^{2+}$-ATPases, i.e. a plasmamembrane and a sarcoplasmic/endoplasmic reticulum $\mathrm{Ca}^{2+}$-ATPase (PMCA, SERCA). Antiporter systems are to be expected, as inferred from indirect evidence. Among the best known cytosolic $\mathrm{Ca}^{2+}$-binding proteins, calmodulin activates $\mathrm{Ca}^{2+}$ influx channels in the somatic cell membrane, but inactivates $\mathrm{Ca}^{2+}$ influx channels in cilia, where it, thus, ends ciliary reversal induced by depolarization via channels in the somatic cell membrane. Centrin inactivates $\mathrm{Ca}^{2+}$ signals after stimulation by its high capacity/low affinity binding

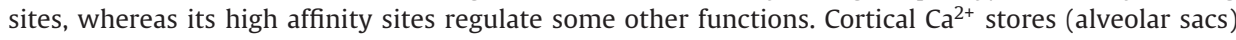
are activated during stimulated trichocyst exocytosis and thereby mediate store-operated $\mathrm{Ca}^{2+}$ entry (SOCE). $\mathrm{Ca}^{2+}$ release channels (CRCs) localised to alveoli and underlying SOCE are considered as Ryanodine receptor-like proteins (RyR-LPs) which are members of a CRC family with 6 subfamilies. These also encompass genuine inositol 1,4,5-trisphosphate receptors $\left(\mathrm{IP}_{3} \mathrm{Rs}\right)$ and intermediates between the two channel types. All IP 3 R/RyR-type CRCs possess six carboxyterminal transmembrane domains (TMD), with a pore domain between TMD 5 and 6, endowed with a characteristic selectivity filter. There are reasons to assume a common ancestor molecule for such channels and diversification further on in evolution. The distinct distribution of specific CRCs in the different vesicles undergoing intracellular trafficking suggests constitutive formation of very locally restricted $\mathrm{Ca}^{2+}$ signals during vesicle-vesicle interaction. In summary, essential steps of $\mathrm{Ca}^{2+}$ signalling already occur at this level of evolution, including an unexpected multitude of CRCs. For dis-/similarities with other bikonts see "Conclusions".
\end{abstract}

\section{Introduction - why study $\mathrm{Ca}^{2+}$ in ciliates?}

Why are ciliated protozoa interesting for $\mathrm{Ca}^{2+}$ signalling in the context of evolution? Paramecium and Tetrahymena are among the protozoan models most frequently used in cell and molecular biology [1]. Recent clades of ciliates have emerged between $\sim 800$ and 850 million years (Myr) ago according to small mRNA analysis [2], evaluation by more extended molecular biology [3] eventually combined with microfossils [4]. The data suggest that the phylum as such is considerably older.

* Correspondence to: Department of Biology, University of Konstanz, Room M1132, P.O. Box M629, 78457 Konstanz, Germany. Tel.: +49 753188 2228; fax: +497531882168 .

E-mail address: helmut.plattner@uni-konstanz.de
Assuming that the Ur-eukaryote arose probably between $\sim 1900$ and $1700 \mathrm{Myr}$ ago $[5,6]$ and soon developed an elaborate and dynamic internal membrane system [7-9], vesicle trafficking must have required adequate signals. For example, for the Ur-eukaryote, 20 types of SNARE (soluble $N$-ethylmaleimide attachment protein receptor) proteins [10] have been extrapolated, about half or less of the number occurring in present day species including Paramecium [11]. The number of small GTPases rose even considerably more during eukaryote evolution from Tetrahymena [12] to man [13]. From unequivocal experience with modern species and from the physicochemical corollaries underlying membrane interaction and fusion, some form of $\mathrm{Ca}^{2+}$ signalling must have been prerequisite already to early development of vesicle trafficking. See contribution by Plattner and Verkhratsky [14]. Thereby early eukaryotes were able to profit from an inventory of $\mathrm{Ca}^{2+}$ binding proteins ( $\mathrm{CaBP})$, influx channels, pumps etc. which they 
inherited from prokaryotes (see chapter by Domínguez et al. [15]).

Choanoflagellates as well as myxamoebae on the one hand and ciliates on the other hand stand for the two main lineages, unikonts and bikonts, leading to the evolution of the most highly evolved groups: from unikonts metazoa and from bikonts flowering plants (angiosperms) have evolved [16,17]. Therefore, it appears rewarding to have a closer look on the ciliate, Paramecium, particularly since this is one of the unicellular organism best analysed with regard to $\mathrm{Ca}^{2+}$ signalling by molecular biology and by a series of experimental approaches [18].

Focussing on ciliates this review also recalls the close evolutionary relationship to pathogenic forms of the phylum Apicomplexa. It is interesting to see changes in evolution due to parasitic lifestyle [19]. See also chapter by Moreno [20]. Precursors leading to Plasmodium have evolved since $\sim 400 \mathrm{Myr}$ [3], the mammalian parasites since $\sim 13 \mathrm{Myr}$ [21]. What these parasites have "forgotten" and "learned" to survive under their specific environment has been outlined previously [19]. A crucial question concerns the possible functional transformation of the alveolar sacs into the "inner lamellar complex" as pointed out in the chapter by Plattner and Verkhratsky [14] in the current issue.

\section{Paramecium as a model and methodologies available}

Over decades Paramecium has been frequently used as a unicellular model by electrophysiologists and by cell biologists [1]. It was the subject of extensive and innovative electrophysiology, yielding basic new insight into signalling processes [22-25], as to be specified in Section 6.1. The highly regular design, together with epigenetic determination of cell surface structure, made Paramecium and Tetrahymena a widely used model also for cell surface pattern formation [26]. The high number of cilia in regular arrangement made ciliates interesting for biogenetic studies on basal body and cilia formation [27] and the numerous, also regularly arranged dense core-secretory organelles, trichocysts, with the possibility of triggering synchronous exocytosis gave a handle to the study of some basic aspects of membrane fusion (exocytosis) and resealing (exocytosis-coupled endocytosis) [28,29]. As these structural redundancies are epigenetically controlled in Paramecium [26] it was possible during evolution to link the two aspects, regular design of the cells with very locally confined $\mathrm{Ca}^{2+}$ signalling by distinctly arranged $\mathrm{Ca}^{2+}$ influx and release channels (Plattner [30]).

About 10 years ago databases became available from a Paramecium and a Tetrahymena genome project [31,32], respectively. This enabled many detailed analyses of $\mathrm{Ca}^{2+}$ signalling particularly in the larger species, Paramecium, that previously were very much dependent on spontaneous and experimentally generated mutations. This explains why functional and molecular data on $\mathrm{Ca}^{2+}$ signalling in ciliates are rather stochastically distributed over the years, for different aspects and with widely different methodologies. First, there was a strong focus on electrophysiology, then on cell biology and more recently on molecular biology. Some of these aspects can now be combined and reconciled.

Paramecium has $\sim 1.8$ times more protein encoding genes than man, i.e. nearly 40,000 , due to several rounds of whole genome duplications [31]. Many paralogues (also called "ohnologues" when generated by whole genome duplication) have been lost after each round. But whenever very similar ohnologues have been maintained they usually are all transcribed, as we found with a variety of protein encoding genes [11]. Therefore, most ohnologues are thought to serve for gene amplification. There are also examples of neofunctionalisation [33]. In the extreme, two ohnologue genes, e.g. for calcineurin B, result in an identical translation product [34]. The absence of such whole genome duplications in Tetrahymena may be considered an advantage in some regards. In contrast, the situation in Paramecium, much more than in Tetrahymena, allows us to have a glance at $\mathrm{Ca}^{2+}$ signalling during ongoing evolution at the basis of bikonts. One may also recognize steadily ongoing parallel evolution at the level of protozoa. This situation lets us expect to see ancestral forms of molecules and further developments similar to those in higher eukaryotes. It is much less likely that ciliates would have acquired elements of $\mathrm{Ca}^{2+}$ signalling by vertical gene transfer [35], as these cells have a very broad and robust inventory of elements serving for $\mathrm{Ca}^{2+}$ signalling [18].

In the 1990s electrophysiological work with Paramecium has largely run dry for several reasons. First, patch-clamp analysis is not applicable because these cells are rather large and possess a pronounced egg case-like, rigid surface, thus precluding tight sealing. Only whole cell patch analysis has been possible to register $\mathrm{Ca}^{2+}$ currents and $\mathrm{Ca}^{2+}$-activated currents along the cell membrane during exocytosis stimulation [36,37]. Second, the registration of $\mathrm{Ca}^{2+}$ transients, i.e. changes in intracellular free $\mathrm{Ca}^{2+}$ concentration, $\left[\mathrm{Ca}^{2+}\right]_{i}$, by $f / f_{\mathrm{o}}$ ratio imaging during stimulation was hampered by several problems. One was that these cells do not easily take up fluorochromes even as esters, and when taken up they are not easily activated and if so, fluorochromes are rapidly sequestered into vacuoles. Another problem was the high mobility of these cells. These difficulties have finally been tackled [38], eventually in combination with fast opto-acustic confocal laser scanning microscopy [39]. $\mathrm{Ca}^{2+}$ signalling was, thus, analysed during synchronous ciliary beat, i.e. during normal beat and during ciliary beat reversal, respectively, as well as during synchronous exocytosis stimulation.

Fluorochrome analyses were complemented by quenchedflow/cryofixation (fast freezing) and energy-dispersive X-ray microanalysis, EDX $[40,41]$. Each of these methods provided us with a temporal resolution of $\sim 30 \mathrm{~ms}$ [29]. This is comparable to the time required for these processes because ciliary beat operates with $\sim 20 \mathrm{~Hz}$ and since exocytosis, though individual events (e.g. of membrane fusion) are much more rapid, is not absolutely synchronous when all events are collectively evaluated in a population of cells. The combination of fluorochrome analysis and EDX allowed us to analyse changes in $\left[\mathrm{Ca}^{2+}\right]_{i}$ and in total calcium [Ca] (predominantly in bound form), respectively, and, therefore, to register $\mathrm{Ca}^{2+}$ fluxes. Higher spatial resolution of the intracellular distribution of $\mathrm{Ca}^{2+}$ was achieved by electron spectroscopic imaging, ESI, which enabled us to clearly identify alveolar sacs as cortical $\mathrm{Ca}^{2+}$ stores [42].

More recently we have identified and partially characterised at a molecular level, and finally localised in Paramecium at the light and electron microscope level SNAREs and other elements relevant for vesicle trafficking $[11,43]$. More recently this has been extended to $\mathrm{Ca}^{2+}$ release channels (CRC) [44-46].

A survey of the handling of $\mathrm{Ca}^{2+}$, of its regulation and of $\mathrm{Ca}^{2+}$ regulated processes in the Paramecium cell is presented in Fig. 1.

\section{3. $\mathrm{Ca}^{2+}$ leakage, sequestration and extrusion and estimation of $\mathrm{Ca}^{2+}$ fluxes}

\section{1. $\mathrm{Ca}^{2+}$ leakage, sequestration and extrusion}

The Paramecium cell has an unexpectedly high leakage rate for $\mathrm{Ca}^{2+}[47,48]$. How is this counteracted to maintain $\left[\mathrm{Ca}^{2+}\right]_{i}$ homeostasis?

The cell membrane of Paramecium possesses a PMCA of $\sim 130 \mathrm{kDa}[49,50]$, i.e. of the usual size. Calmodulin binding has not been assessed and it is also unknown whether the PMCA extends to 


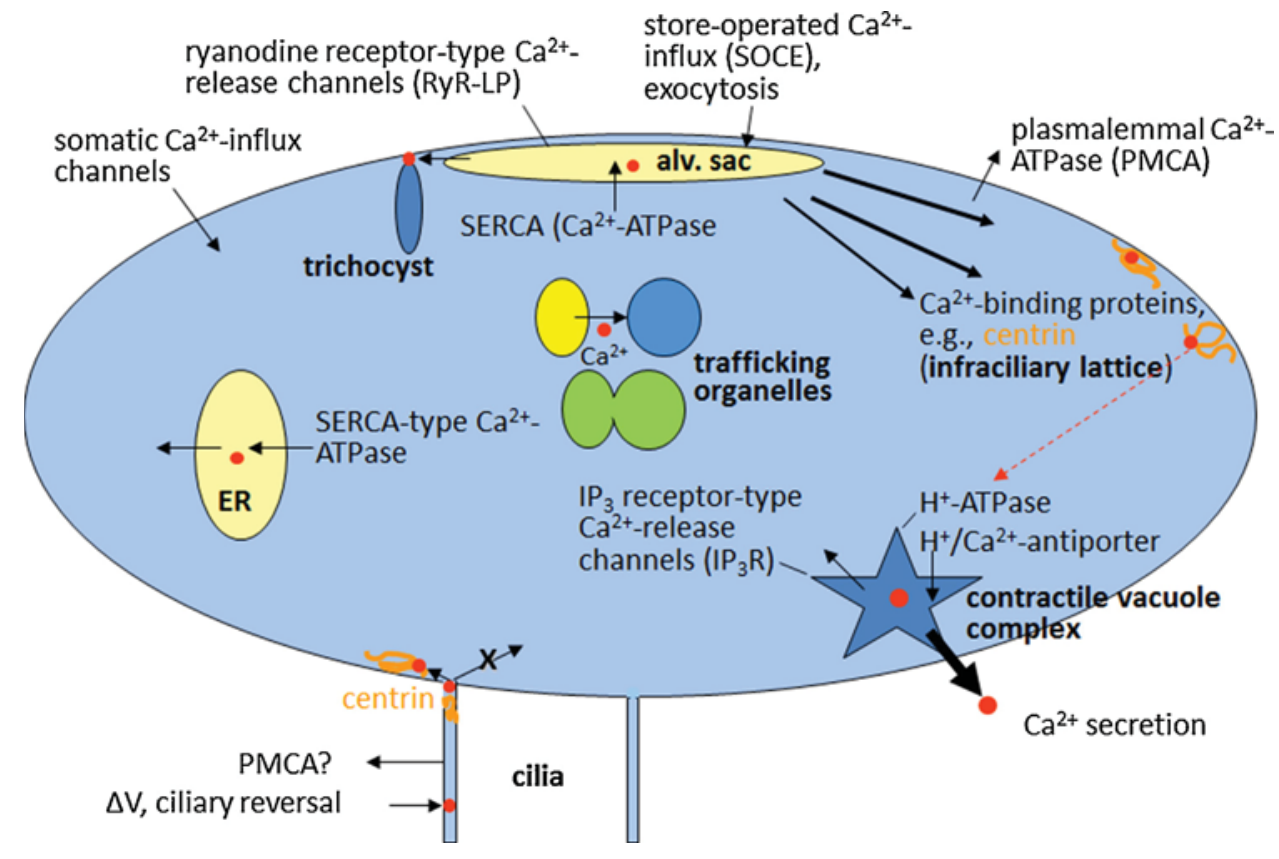

Fig. 1. Expanded scheme of vesicle trafficking, based on Plattner [18] and a basic trafficking concept outlined by Allen and Fok [107], with sites of Ca ${ }^{2+}$ influx, pumps, stores and local release. Red dots symbolise $\mathrm{Ca}^{2+}$. $\mathrm{Ca}^{2+}$ influx can occur via widely distributed channels, including voltage-dependent influx channels (in cilia only) and a SOCE type mechanism for exocytosis, operated by non-ciliary channels. PMCA can extrude $\mathrm{Ca}^{2+}$ (though with restricted capacity), its occurrence in the ciliary membrane requiring confirmation. Inside the cell, a SERCA type pump sequesters $\mathrm{Ca}^{2+}$ into the ER and into alveolar sacs. Any uptake mechanisms in other organelles, e.g. of the endo-/phago/lysosomal apparatus are not known, but $\mathrm{Ca}^{2+}$ content is concluded from the CRCs found in these organelles. Ca ${ }^{2+}$ is also sequestered into the contractile vacuole complex; here, occurrence of a PMCA (as in some other protozoa) is not known, but strong evidence argues in favour of $\mathrm{Ca}^{2+}$ sequestration and extrusion via secondary active transport coupled to the organellar $\mathrm{H}^{+}$-ATPase. $\mathrm{IP}_{3} \mathrm{Rs}$ and RyR-LPs have been analysed specifically in the contractile vacuole complex and in the alveolar sacs, respectively. IP ${ }_{3}$ Rs serve for partial reflux of $\mathrm{Ca}^{2+}$ after sequestration. Globally the contractile vacuole complex extrudes $\mathrm{Ca}^{2+}$ constitutively and particularly also following stimulated [Ca $\left.{ }^{2+}\right]_{i}$ increase and, thus, is a substantial control mechanism for $\left[\mathrm{Ca}^{2+}\right]_{i}$ homeostasis. $\mathrm{Ca}^{2+}$ release from alveolar sacs via RyR-LPs serves as ignition for SOCE during stimulation of trichocyst exocytosis. Centrin is shown as a representative of cytosolic CaBPs with activation effects in cilia and downregulation effects in the cortical filament system, the infraciliary

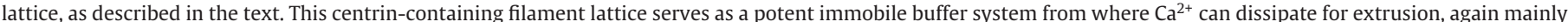
by the contractile vacuole complex. See Fig. 5 for details.

the ciliary membrane. Furthermore, the cells contain two isoforms of a SERCA, 105 to $110 \mathrm{kDa}$ in size and devoid of a calmodulin binding domain [51]. The domain usually accounting for thapsigargin binding greatly differs from mammalian SERCA and no inhibitory effect is achieved [51,52]. Carboxyterminal attachment of green fluorescent protein revealed formation of SERCA molecules in the ER and vesicular transport to alveolar sacs where, according to immune-electron microscopy, it localises to the inner part facing the cell centre [53]. Theoretically both, PMCA and SERCA (in the ER and in alveolar sacs), could keep $\left[\mathrm{Ca}^{2+}\right]_{i}$ low and also contribute to downregulation after stimulation.

However, kinetics of both these P-type ATPases is rather slow [54]. For instance, refilling of alveolar sacs after massive exocytosis stimulation has a $t_{1 / 2}=60 \mathrm{~min}$, as determined by three independent methods [55]. Even in mammalian cells PMCA has been recently envisaged less for household functions, i.e. overall $\left[\mathrm{Ca}^{2+}\right]_{i}$ regulation, but rather for maintaining local subplasmalemmal $\left[\mathrm{Ca}^{2+}\right]$ low [56]. As extensively discussed previously, primary active $\mathrm{Ca}^{2+}$ transport cannot explain rapid downregulation of $\left[\mathrm{Ca}^{2+}\right]_{i}$, e.g. after synchronous exocytosis stimulation [54]. A much more efficient way is secondary active transport via the contractile vacuole complex [46]. The contractile vacuole secretes $\mathrm{Ca}^{2+}$ in unexpectedly high concentration even in resting cells [57]. $\mathrm{Ca}^{2+}$ extrusion by this organelle works on the basis of its extensive endowment of the organelle with a $\mathrm{V}$-type $\mathrm{H}^{+}$-ATPase [58-60]. Its relevance can easily be seen after a $\mathrm{Ca}^{2+}$ load (Section 6.5).

Fig. 2 presents signals recorded during spontaneous exocytosis by electrophysiology $[36,37]$ and by confocal fluorochrome imaging [39]. Fig. 3 summarises results obtained during caffeine stimulated exocytosis [61].

\section{2. $\mathrm{Ca}^{2+}$ fluxes during stimulation}

In Paramecium, exocytosis stimulation entails $\mathrm{Ca}^{2+}$ mobilisation from cortical stores, the alveolar sacs, paralleled by $\mathrm{Ca}^{2+}$ influx via the somatic (non-ciliary) cell membrane. Such store-operated $\mathrm{Ca}^{2+}$ entry, SOCE, has been documented by widely different methods $[39,40,62]$. In Paramecium, from [Ca] in alveolar sacs and the percentage of its mobilisation one can calculate that, referred to the entire cell, a total $\left[\mathrm{Ca}^{2+}\right]$ of $0.25 \mathrm{mM}$ would result if $\mathrm{Ca}^{2+}$ would not be rapidly downregulated by binding to $\mathrm{Ca}^{2+}$-binding proteins, CaBPs [54], as characterised in Section 4.1. These remove $\mathrm{Ca}^{2+}$ from the cytosol considerably faster than any pump activity. In combination with SOCE, exocytosis stimulation would cause a global increase to $\sim 0.85 \mathrm{mM}$ in the entire cell, if not rapidly counteracted. In contrast, only $\sim 5 \mu \mathrm{M}\left[\mathrm{Ca}^{2+}\right]$ are locally required to drive exocytosis and only $\sim 0.7 \mu \mathrm{M}$ are seen with fluorochromes along the cell boundary [38]. How can this be reconciled? First, only a fraction of $\mathrm{Ca}^{2+}$ is seen with fluorochromes and real local values can be determined only by injection of $\mathrm{Ca}^{2+}$ chelators with different time constant [38]. Second, $\left[\mathrm{Ca}^{2+}\right]$ is rapidly downregulated in Paramecium by centrin, as ascertained with mutants devoid of centrin-binding proteins and concomittantly of centrin filament assembly in the cortex [63] (See Fig. 5C).

Is such excessive $\mathrm{Ca}^{2+}$ flux in the course of stimulation restricted to ciliates? Comparable phenomena were registered by electrophysiology with endocrine cells [64]. Also here an excess is required to reach local activation levels for a subsecond time period, while $\mathrm{Ca}^{2+}$ rapidly diffuses and is rapidly bound to immobile buffers. Similar balance calculations, based on electrophysiology with mammalian cells, yield a similar picture as with ciliates, thus 
A
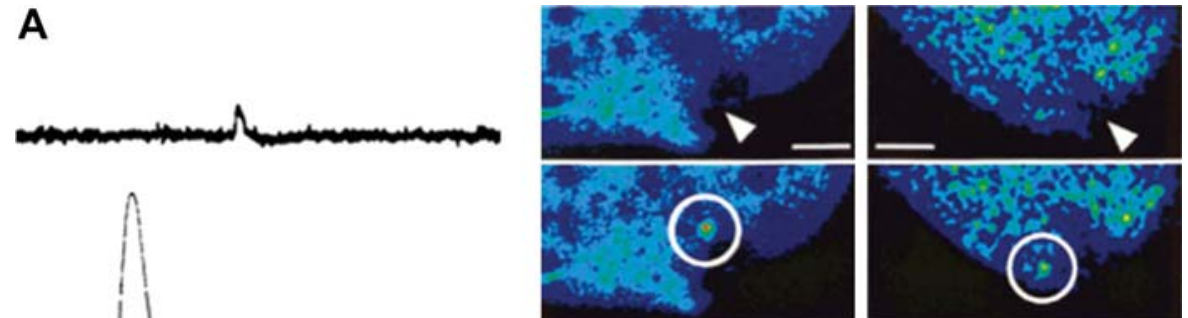
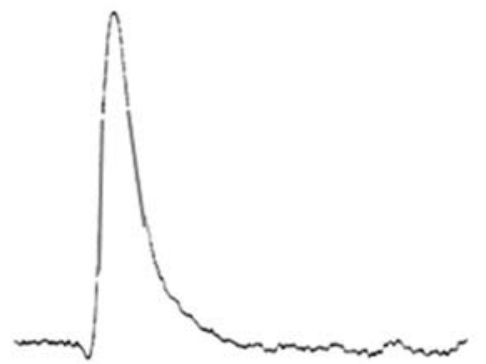

B
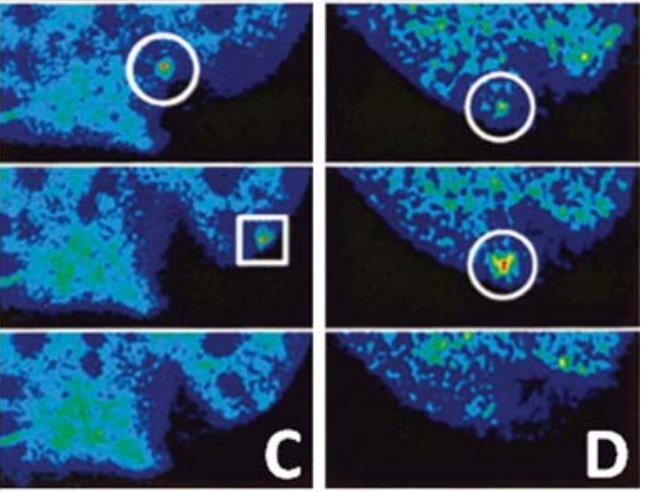

Fig. 2. Mini-Ca ${ }^{2+}$ signals accompanying exocytosis of trichocysts. (A) Electrophysiological whole cell-patch recording of Ca ${ }^{2+}$-activated currents paralleled by individual spontaneous exocytotic events (only one shown). (B) Averaged curves from recordings as in (A), showing a duration of $\mathrm{Ca}^{2+}$-activated currents of $\sim 80 \mathrm{~ms}$, with $t_{1 / 2}=21 \mathrm{~ms}$. (A, B) are from Erxleben et al. [37]. (C, D) $\mathrm{Ca}^{2+}$ signals recorded by fluorochrome during release of individual trichocysts by locally (arrowheads) applied small doses of trigger agents, i.e. $\mathrm{AED}(\mathrm{C})$ and $4 \mathrm{CmC}(\mathrm{D})$, respectively, visualized by confocal microscopy. (C, D) are from Klauke et al. [39]; scale bars = $5 \mu \mathrm{m}$.
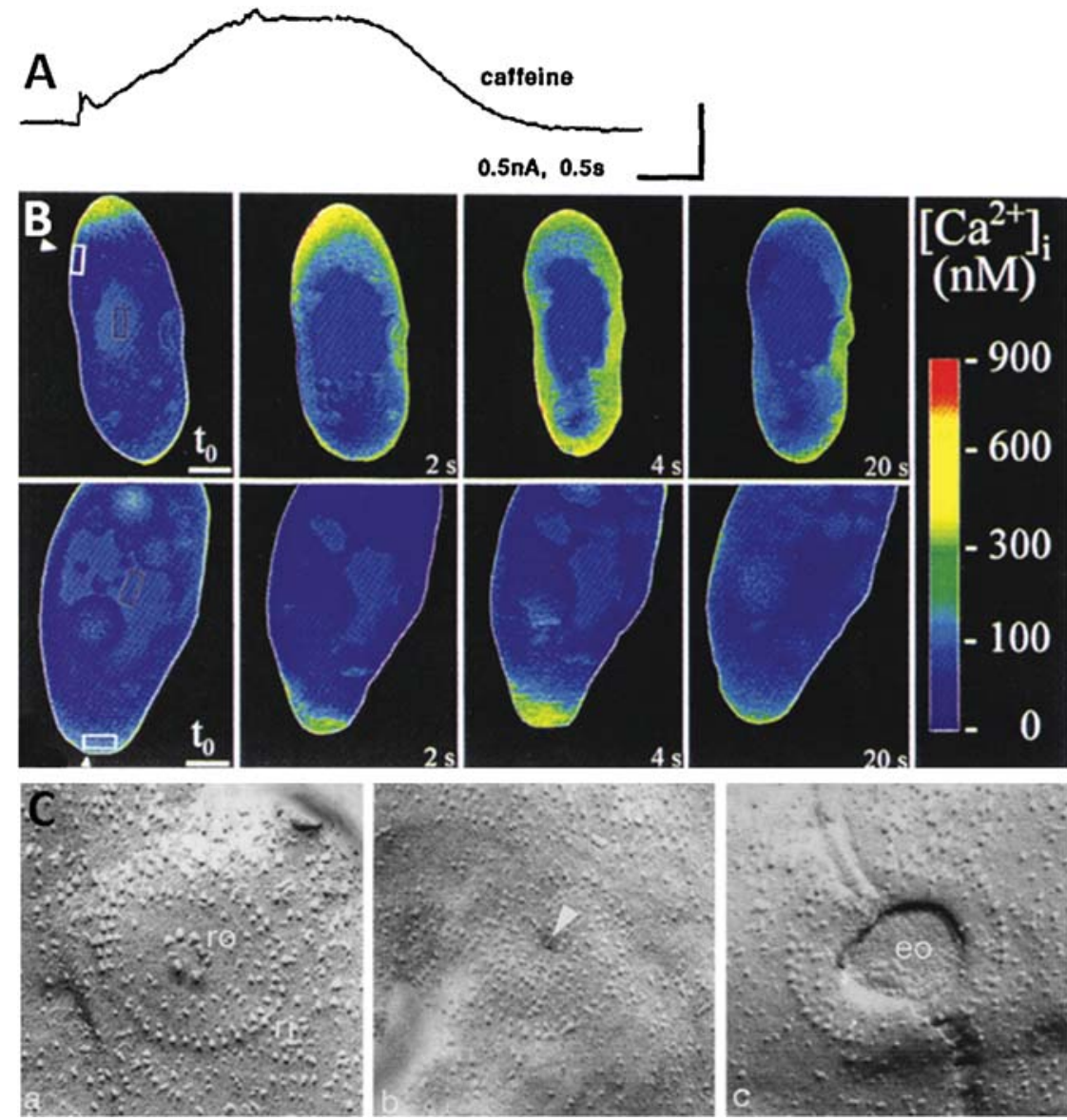

Fig. 3. Caffeine as a trigger for trichocyst exocytosis. (A) Electrophysiological whole cell-patch recording of Ca ${ }^{2+}$-activated current generated by massive exocytosis of trichocysts. (Note that exocytosis induced by caffeine is much less synchronous than that induced by AED.) From Erxleben and Plattner [36]. (B) Fluorochrome imaging of $\mathrm{Ca}^{2+}$ signals generated during exocytosis induced by caffeine (applied at arrowhead), with $\left[\mathrm{Ca}^{2+}\right]_{o}=50 \mu \mathrm{M}$ (top row) and $\left[\mathrm{Ca}^{2+}\right]_{o}$ shortly reduced to $\sim 0.03 \mu \mathrm{M}$ during stimulation (bottom row), respectively, at times from $t_{0}$ (before application) to $20 \mathrm{~s}$. Scale bars $=10 \mu \mathrm{m}$. Squares are the areas evaluated by $f / f_{0}$ ratio analysis, calibrated under the assay conditions at the right; at $t_{0}$, basic cortical $\left[\mathrm{Ca}^{2+}\right]_{i}$ varied between 0.05 and $0.08 \mu \mathrm{M}$. Note the occurrence of a reduced signal at [Ca $\left.{ }^{2+}\right]_{0}$ lowered to a level slightly below $\left[\mathrm{Ca}^{2+}\right]_{i}$ at rest, thus excluding a CICR and rather suggesting a SOCE mechanism. (C) Freeze-fracture demonstration of exocytotic membrane fusion produced by caffeine, as seen after rapid freezing within $1 \mathrm{~s}$ of stimulation. In (a) the resting state is presented, showing a ring (ri) of protein particles delineating the exocytosis site, $0.3 \mu \mathrm{m}$ wide, and an aggregate of larger protein particles in the form of a rosette (ro). Image (a) is before stimulation, (b) shows focal (point fusion [28,29]) at the arrowhead and (c) the expansion to a large exocytotic opening. (B, C) are from Klauke and Plattner [61]. 
stressing the importance of signalling by an excess of $\mathrm{Ca}^{2+}$ because of rapid $\left[\mathrm{Ca}^{2+}\right]$ downregulation below a minimal local level. Over longer times, after synchronous exocytosis induction, inhibition of the $\mathrm{H}^{+}$-ATPase by concanamycin A considerably slows down reestablishment of $\left[\mathrm{Ca}^{2+}\right]_{i}$ in Paramecium [19]. On the one hand this stresses the importance of secondary active $\mathrm{Ca}^{2+}$ transport over longer times and on the other hand assigns the main regulatory function over short times to CaBPs, i.e. centrin in ciliates.

Not only exocytosis, but also exocytosis-coupled endocytosis depends on $\left[\mathrm{Ca}^{2+}\right]_{0}$. Thus, both are driven by SOCE [65]. Again this is well comparable with mammalian cells [66] where the C2-type CaBP synaptotagmin is involved also in this second step of exoendocytosis coupling [67]. Remarkably, in the calyx of Held, a large synapse in the mammalian auditory central nervous system, two different $\mathrm{Ca}^{2+}$ influx channels, localised side-by-side, contribute to the two phenomena, exocytosis and exocytosis-coupled endocytosis [68]. Thus, this tight temporal coupling of exocytosis and endocytosis on the basis of a local $\mathrm{Ca}^{2+}$ signal is a widely distributed phenomenon.

In cilia of Paramecium, under our standard conditions, induction of $\mathrm{Ca}^{2+}$ influx by depolarization would cause an increase of $\left[\mathrm{Ca}^{2+}\right]$ to an estimated $50 \mu \mathrm{M}$, corresponding $\sim 700 \mathrm{Ca}^{2+}$ molecules per organelle, if free $\mathrm{Ca}^{2+}$ were not downregulated immediately [41]. The range of estimations based on electrophysiology is between $10 \mu \mathrm{M}$ and $1 \mathrm{mM}$, depending on $\left[\mathrm{Ca}^{2+}\right]_{o}[69,70]$. Again centrin may be involved in rapid inactivation (Section 4.1). Under standard conditions no spillover of $\mathrm{Ca}^{2+}$ from cilia into the cytosol can be recognized [41].

In summary, the high leakage rate of $\mathrm{Ca}^{2+}$ is compensated more by secondary, rather than by primary active transport activity. This is paralleled by rapid binding to immobile buffers, i.e. CaBPs, from where $\mathrm{Ca}^{2+}$ diffuses, also for extrusion mainly by the contractile vacuole complex.

\section{4. $\mathrm{Ca}^{2+}$-binding proteins}

Principally CaBPs contain different motifs enabling binding of $\mathrm{Ca}^{2+}$. First, this can take place with low specificity/affinity, but high capacity, as is the case with calreticulin and calsequestrin in the lumen of $\mathrm{Ca}^{2+}$ stores. (Here, $\mathrm{Ca}^{2+}$ specificity is guaranteed by the selectivity of the uptake mechanism.) Such molecules are rich in acidic aminoacids. Second, there are low capacity/high affinity CaBPs endowed with EF-hand motifs for coordinative binding of $\mathrm{Ca}^{2+}$ via loops of 12 aminoacids, such as calmodulin [71] and centrin, although centrin also contains a stretch with abundant acidic residues also in Paramecium [72,73]. Third, some other proteins bind $\mathrm{Ca}^{2+}$ with low capacity/high affinity by $\mathrm{C} 2$ motifs, i.e. $\beta$-barrels with a $\mathrm{Ca}^{2+}$ binding loop [74]. Moreover, there are still other CaBPs in the cytosol, such as annexins and copines (Section 4.1).

\subsection{Cytosolic $\mathrm{Ca}^{2+}{ }_{-}$binding proteins}

Calmodulin (CaM) is enriched at several sites of the Paramecium cell [75,76]: along the cell membrane, in cilia and on vesicles of the food vacuole (phagolysosome) system as well as along the contractile vacuole and its extensions [75]. Here, CaM is associated with microtubules [76], so one can expects a stabilizing effect [77]. At the cell membrane CaM activates $\mathrm{Ca}^{2+} / \mathrm{CaM}$-activated cation influx channels (Section 6.1) and the PMCA has a CaM binding domain for its activation [50] (although CaM binding still remains to be ascertained with Paramecium). This may also be the case with the contractile vacuole, provided it contains PMCA as in other species - a currently open question [77]. At the ciliary membrane of Paramecium $\mathrm{Ca}^{2+}$ occupancy of specific EF-hand loops in the centrin molecule is required to activate voltage-dependent $\mathrm{Ca}^{2+}$ influx channels [78] whereas a $\mathrm{Ca}^{2+} / \mathrm{CaM}$ complex deactivates these channels (Section 6.1). $\mathrm{A} \mathrm{Ca}^{2+} /$ calmodulin complex activates guanylate cyclase [79] and cyclic GMP in turn activates protein kinase G (PKG) [80]. Both, the cyclase and the PKG are localised to cilia [81] where the cascade of events controls ciliary reversal. Finally the assembly of functional trichocyst docking sites with exocytosis competence depends on CaM [82] and CaM is also localised to these sites [75]. CaM is required for the assembly of exocytosis sites up to mammalian nerve terminals $[83,84]$.

CaM-like domains are integrated in $\mathrm{Ca}^{2+}$-dependent protein kinases, CDPK, of ciliates [73] and higher plants [85]. $\mathrm{Ca}^{2+} / \mathrm{CaM}-$ activated protein kinases ("CaM kinases") proper are rare in plants (see contribution by Edel and Kudla [86]) and evidently absent from ciliates. Beyond that a $\mathrm{Ca}^{2+}$-inhibitable casein kinase-type protein kinase has been cloned in Paramecium [87]. It antagonizes dephosphorylation of an exocytosis sensitive phosphoprotein of $63 \mathrm{kDa}$, pp63 (phosphoglucomutase), by the $\mathrm{Ca}^{2+} / \mathrm{CaM}$-activated protein phosphatase $2 \mathrm{~B}$, calcineurin $[34,88]$. This process has been discussed in detail by [89] and is considered important for ATP regeneration during rapid synchronous trichocyst exocytosis.

Centrin has in part EF-hand motifs and in part a domain with a surplus of acidic aminoacids [73]. Whereas the first aspect is interesting for the interaction with the voltage-dependent $\mathrm{Ca}^{2+}$ channels in cilia (see above) which thus are activated [78], the second aspect efficiently adsorbs an excess of free $\mathrm{Ca}^{2+}$. Centrin is not only a main component of the infraciliary lattice of Paramecium $[63,72,73]$, but also occurs at the basis of cilia in Tetrahymena [90]. Here it is enriched also in the transition zone [91] and, therefore, can act like a pump. Activation of the infraciliary lattice by a $\mathrm{Ca}^{2+}$ load causes cell contraction. Both functions are downregulated in mutants devoid of a centrin-binding protein [63,72] (Fig. 5C). Centrin is also engaged in morphogenetic processes in Paramecium [74] and in Tetrahymena [90]. Thus, differential duties can be assigned to the centrin molecule, as is the case also in human epithelial cells [92].

The C2-type CaBP, synaptotagmin, has two C2 domains and, due to its fast kinetics, enables membrane fusion in connection with SNAREs [94]. In the Paramecium database only an equivalent with eight C2 domains is found (R. Kissmehl and H. Plattner, unpubl. observ.), as confirmed by others (pers. commun.). Such multiple C2 domain CaBPs are also present in some intracellular membranes of mammalian cells [93] and here such extended-(e-)synaptotagmins can substitute for synaptotagmin proper [94]. Remarkably, the actual local $\left[\mathrm{Ca}^{2+}\right]_{i}$ at exocytosis sites during stimulation is $\sim 5 \mu \mathrm{M}$ in Paramecium [38] and, thus, in the range of C2-domain proteins. Unfortunately universality of $\mathrm{CaBPs}$ with $\mathrm{C2}$-domains and their role in membrane fusion have not been analysed consistently in many systematic groups including ciliates.

Copines, another group of cytosolic C2-domain proteins, have been detected and cloned in Paramecium [95]. Annexins are cytosolic and membrane binding CaBPs with alternative $\mathrm{Ca}^{2+}$ binding motifs [96]. In Paramecium, using antibodies against common (mammalian) sequences, putative annexins have been found associated with preformed exocytosis sites, specifically with trichocyst docking sites and with the cytoproct (the site of release of spent food vacuoles) [97]. Both, copines and annexins are considered important for establishment of membrane-to-membrane links $[96,98]$ and both occur in animals as well as in plants where they deal with $\mathrm{Ca}^{2+}$-dependent developmental and defence processes $[99,100]$.

In an evolutionary context CaBPs can be summarised as follows. Many of the functions of CaM are maintained up to the top of multicellular uni- and bikonts. However, there also occurs some diversifications between uni- and bikonts. The occurrence of voltage-dependent $\mathrm{Ca}^{2+}$ influx channels in unikonts is in contrast to 
higher plants where they are absent, as discussed by Edel and Kudla [86]. Their regulation by CaM in mammalian pyramidal neurons [101] is as occurring in ciliates. CaM-like sequences integrated in CDPKs are typical of bikonts, i.e. ciliates and plants (Edel and Kudla [86]). No such dual distribution is found with annexins, centrin and copines, as they occur in both lineages.

\subsection{Lumenal $\mathrm{Ca}^{2+}$-binding proteins}

Genes encoding calreticulin and calsequestrin have not been found in the Paramecium database. However, monospecific antibodies provided by a leading expert, H.-D. Söling (Göttingen), clearly differentiated between ER and alveolar sacs, the cortical $\mathrm{Ca}^{2+}$ stores resembling very much the SR of muscle [102]. Difficulties in finding gene sequences can be explained by the importance of the abundant acidic aminoacid residues, rather than of specific motifs [103].

Different dense core-secretory organelles of mammalian cells also store $\mathrm{Ca}^{2+}$, occasionally in tens of millimolar concentrations. This is in striking contrast to trichocysts of Paramecium. These contain no $\mathrm{Ca}^{2+}$ detectable by EDX [40]. Whereas this could be due to low sensitivity of the method, biological arguments support the absence of any remarkable $\mathrm{Ca}^{2+}$ in the organelles. First, in vitro, $\mathrm{Ca}^{2+}$ in (sub)millimolar concentrations causes vigorous decondensation (stretching) of the trichocyst matrix [104], an effect normally coupled with formation of an exocytotic opening which gives $\mathrm{Ca}^{2+}$ access to the lumen. Second, the relevance of $\mathrm{Ca}^{2+}$ binding to the trichocyst contents just during exocytosis is supported by the finding of CaBPs in the trichocyst matrix in wildtype cells [105]; in contrast, a mutant unable decondense trichocysts in vitro upon addition of $\mathrm{Ca}^{2+}$ is also unable to bind ${ }^{45} \mathrm{Ca}^{2+}$ to trichocyst contents on electrophoresis gels. In such a mutant, trichocysts also do not decondense in vivo even though an exocytotic fusion pore has been formed upon stimulation with a secretagogue [105]. Evidently, in Paramecium, membrane fusion and contents release are two distinct steps of exocytosis which, however, are automatically coupled by the access of $\mathrm{Ca}^{2+}$ to the secretory contents. This aspect would deserve detailed analysis also in metazoan secretory cells.

\section{Dedicated $\mathrm{Ca}^{2+}$ stores and $\mathrm{Ca}^{2+}$ in trafficking organelles}

\subsection{The endoplasmic reticulum, alveolar sacs and trafficking organelles}

There is no continuity between the two stores and the sacs must, therefore, be formed by vesicle trafficking $[53,106]$. They share the SERCA [53] and in part also CRCs [45]. [Ca] in the sacs is $\sim 40 \mathrm{mM}$ according to calibrated EDX analysis [40].

Much more elaborate is trafficking via the endocytotic, phagocytotic and exocytotic route as well as along different membrane recycling routes, for instance to and from the food vacuoles (phagosomes and phagolysosomes), as established by Allen and Fok [107]. Surprisingly the contractile vacuole complex which undergoes cyclic kiss-and-run exocytosis contains SNAREs as molecular attributes of vesicle trafficking not only at the pore (exocytotic outlet), but also within the organelle [77]. This reflects membrane trafficking by marching on the spot, meaning restructuring of the complex spongiome-like membrane network [77]. Its $\mathrm{Ca}^{2+}$ content can be seen in the electron microscope after appropriate preparation [18] and by $\mathrm{Ca}^{2+}$ selective electrode recordings [57,108].

No data are available for the $\mathrm{Ca}^{2+}$ content in the trafficking organelles of Paramecium. This must be assumed, however, considering their endowment with distinct CRCs and the known $\mathrm{Ca}^{2+}$ content in equivalent structures in higher eukaryotes, as outlined in Section 6.

\subsection{Crystal vacuoles}

According to X-ray diffraction analysis the membrane-bounded crystals contain $\mathrm{Ca}^{2+}$ as $(\mathrm{Mg}, \mathrm{Ca}) \mathrm{NH}_{4} \mathrm{PO}_{4} \cdot 6 \mathrm{H}_{2} \mathrm{O}$, struvite, one of the minerals also contained in kidney stones [109]. Their number increases with cell age and they may, therefore, serve as a waste basket, but their role in $\mathrm{Ca}^{2+}$ regulation is unexplored.

\subsection{Mitochondria and $\mathrm{Ca}^{2+}$ handling in ciliates}

A mitochondrial $\mathrm{Ca}^{2+} u$ niporter, MCU serves for rapid uptake of $\mathrm{Ca}^{2+}$ into the organelle. A homolog occurs in Tetrahymena [110]. In contrast, the essential MCU regulator, EMRE, has not been found in the Tetrahymena database [111].

During exocytosis stimulation, [Ca] is seen by EDX to rise in mitochondria within $30 \mathrm{~ms}$ and then to decay already within $80 \mathrm{~ms}$ [40]. With the mitochondrial fluorochrome, Rhodamine, $\left[\mathrm{Ca}^{2+}\right]$ rise in mitochondria is also very fast, but the decay of $\left[\mathrm{Ca}^{2+}\right]$ is by orders of magnitude slower, $\geq 5$ min [19]. This indicates that only a fraction of $\mathrm{Ca}^{2+}$ is retained in the mitochondria. Interestingly, in Paramecium, mitochondria are enriched in cortical regions (unpubl. observ.). This may not only contribute to the regulation of $\left[\mathrm{Ca}^{2+}\right]_{i}$ homeostasis, but it may also contribute to energetics by activation of matrix dehydrogenases [112]. Such cortical localisation is considered a principal aspect of energetics in many unicellular organisms [113].

\section{6. $\mathrm{Ca}^{2+}$ influx and intracellular $\mathrm{Ca}^{2+}$ release channels in ciliates}

A Paramecium cell contains numerous $\mathrm{Ca}^{2+}$ influx and release channels which all are distributed over the cell in a rather precise pattern (see chapter by Plattner [30]). This allows for precise local $\mathrm{Ca}^{2+}$ signalling.

\section{1. $\mathrm{Ca}^{2+}$ influx channels}

Paramecium cells dispose of an ample assortment of $\mathrm{Ca}^{2+}$ influx channels and of $\mathrm{Ca}^{2+} /$ calmodulin-activated channels in their somatic (non-ciliary) cell membrane [22,23,24]. Different channels have to cooperate for a specific ciliary/behavioural response. In part, this is guaranteed by their specific localization. For instance, voltage-gated $\mathrm{Ca}^{2+}$ channels do not occur outside cilia [114]. They are activated by depolarization of the cell membrane potential which in turn occurs in the course of mechanical stimulation of the cell in its anterior part where mechanosensitive channels are found in the somatic cell membrane [115]. Thus, a receptor potential is generated and depolarisation beyond a threshold induces a graded action potential by the voltage-dependent $\mathrm{Ca}^{2+}$ channels [116]; the membrane potential is reversed by $\mathrm{Ca}^{2+}$-activated $\mathrm{K}^{+}$ efflux. The activity of voltage-gated $\mathrm{Ca}^{2+}$ channels is supported by associated centrin [78] and rapidly counteracted by the forming $\mathrm{Ca}^{2+} /$ calmodulin complex which inactivates the voltage-dependent $\mathrm{Ca}^{2+}$ channels [117]. This inactivation mechanism is maintained in evolution up to pyramidal cells of the human brain [101]. When hyperpolarising $\mathrm{K}^{+}$channels are activated in the posterior part of the cell surface, hyperpolarization-sensitive $\mathrm{Ca}^{2+}$-channels in the somatic cell membrane activate another signalling cascade resulting in accelerated forward swimming [118]. This channel distribution has been summarized in more detail in an accompanying article by the author [30]. Voltage-dependent $\mathrm{Ca}^{2+}$ influx and its regulation in ciliates seem to be an old heritage which has been lost in the bikont lineage, i.e. plants (see Edel and Kudla [86]). 


\subsection{Inositol 1,4,5-trisphosphate receptors}

A broad variation in the collection of CRCs of the type inositol 1,4,5-trisphosphate $\left(\mathrm{InsP}_{3}\right)$ receptors $\left(\mathrm{IP}_{3} \mathrm{R}\right)[46]$ and Ryanodine receptor-(RyR-)like proteins (RyR-LPs) [45], respectively, together with intermediate forms [44], has been detected in Paramecium. Epigenetically determined intracellular distribution of many of these CRCs is discussed in a separate article by the author in this issue [30]. Only a few of these channels have been followed up in more detail experimentally.

$\mathrm{IP}_{3} \mathrm{Rs}$ of Paramecium, type CRC-II, contain a genuine $\mathrm{InsP}_{3}-$ binding domain according to ${ }^{3} \mathrm{H}$-inositol 1,4,5-trisphosphate binding to the homologously overexpressed and isolated protein, Ins $\mathrm{P}_{3}$ uncaging experiments paralled by $\left[\mathrm{Ca}^{2+}\right]_{i}$ recording, and molecular modelling [46]. The finding of $\mathrm{IP}_{3} \mathrm{Rs}$ in the contractile vacuole complex/osmoregulatory system was insofar surprising as these complex organelles extrude $\mathrm{Ca}^{2+}$ with every pulsation $[57,108]$. However, a stochastic, non-stimulated $\mathrm{Ca}^{2+}$ reflux is clearly seen with fluorochromes. This indicates constitutive activity of the $\mathrm{IP}_{3} \mathrm{R}$, as then also seen in avian and mammalian cell cultures [119]. In Paramecium, this could serve for fine-tuning of $\left[\mathrm{Ca}^{2+}\right]_{i}$. Since these CRCs are localised to the smooth spongiome - a widely branched tubular membrane system undergoing extensive rearrangements during systole/diastole cycles of the contractile vacuole $[120,121]$ - and considering the presence of $\mathrm{v}$ - and $\mathrm{t}$ SNAREs in this region [43,77], $\mathrm{Ca}^{2+}$ most likely also contributes to the periodic rearrangement of this extensive and dynamic membrane system during each functional cycle of $\sim 8 \mathrm{~s}$ [77].

\subsection{Ryanodine receptor-like proteins in Paramecium}

The identification of RyRs, or rather RyR-LPs, is more difficult, particularly since these molecules are remarkably smaller in Paramecium than in higher eukaryotes [45]. One type analysed in more detail is important for the release of $\mathrm{Ca}^{2+}$ from the cortical $\mathrm{Ca}^{2+}$ stores, the alveolar sacs, as summarised in Fig. 4. As mentioned, this involves a SOCE mechanism. This has been concluded unanimously from whole cell-patch electrophysiology [36], fluorochrome analysis $[38,39]$ and quenched-flow/EDX [40]. For instance, rapid substitution of $\mathrm{Sr}^{2+}$ for $\mathrm{Ca}^{2+}$ in the medium during quenched-flow stimulation clearly showed, during exocytosis stimulation, the release of $\mathrm{Ca}^{2+}$ and the rapid emergence of $\mathrm{Sr}^{2+}$ $K \alpha$ energy signals in the alveolar sacs [40]. When cells were stimulated at extracellular $\mathrm{Ca}^{2+}$ concentrations, $\left[\mathrm{Ca}^{2+}\right]_{o}$, slightly below $\left[\mathrm{Ca}^{2+}\right]_{i}$ at rest, there was still some fluorochrome signal generated by stimulation [38] and, in EDX, $\mathrm{Ca}^{2+}$ in the alveoli decreased by $\sim 50 \%$ [40]. To definitely exclude $\mathrm{Ca}^{2+}$-induced $\mathrm{Ca}^{2+}$ release, CICR, we stimulated mutant cells devoid of $\mathrm{Ca}^{2+}$ influx; the result was as with wildtype cells [62] - again excluding a CICR (Fig. 5A). Originally aminoethyldextran, AED, has been used to stimulate cells, not only because this perfectly mimics the physiological situation during predator defence by massive local trichocyst exocytosis and superimposed ciliary reversal for escape [18], but also because it can be used in multiple rounds for exocytosis stimulation without any recognizable side-effects [122]. In connection with molecular biology work, the RyR agonists, caffeine and 4-chloro-meta-cresol, $4 \mathrm{CmC}$, have been applied [45]. In fluorochrome analyses, the results were all the same as with AED, i.e. the same signals were registered with caffeine and $4 \mathrm{CmC}$ when stimulated at normal $\left[\mathrm{Ca}^{2+}\right]_{o}$ and at reduced $\left[\mathrm{Ca}^{2+}\right]_{0}$, respectively [45]; Fig. 4A-C. Moreover, gene silencing almost abolished the signal normally seen upon stimulation (Fig. 4D).

A notoriously aberrant pharmacology of ciliates (e.g. actin isoforms insensitive to phalloidin, SNARE proteins insensitive to Clostridium toxins, SERCA insensitive to thapsigargin, etc. [52]) makes tests with ryanodine unreasistic. Is there any other support for the assumption of the occurrence of RyRs or RyR-LPs in Paramecium? Response to the alkaloid ryanodine from the South American plant, Ryania speciosa (Salicaceae), can hardly be considered an ultimate selection characteristic, unless specific functional/molecular clues would be evident (which is not the case). Unfortunately CADPR, a potential signal transducer for these channels [123], has not been established at the time we made our analyses. Experience with the secretagogues, caffeine and $4 \mathrm{CmC}$, in general and with Paramecium in particular [39,61] agree with the assumption of RyRs/RyR-LPs $[44,45]$ and SOCE in Paramecium. The aminoacid signature critical for $4 \mathrm{CmC}$ binding [124] is present in the Paramecium RyR-LP molecule [45]; Fig. 4E. This, together with the insensitivity to ryanodine makes it similar to a RyR in malignant insomnia patients [125]. Also the position in a subcellular compartment reminds the terminal cisternae in muscle, as does the SOCE mechanism - another characteristic of skeletal muscle cells [126]. The lumenal high capacity/low affinity CaBP found in the alveolar sacs lumen [102] is also equivalent to that in the sarcoplasmic reticulum (see above). Furthermore, the channel identified to respond to exocytosis stimulation does not respond to $\mathrm{InsP}_{3}$ uncaging [46]. Finally, by electrophysiological recording of Paramecium surface membrane proteins reconstituted with liposomes, a non-InsP ${ }_{3}$ sensitive, non-plasmalemmal channel has been seen that "may reflect a $\mathrm{Ca}^{2+}$ release channel of the alveolar sacs" [127]. Collectively all these arguments support the hypothesis that the channels, CRCII, found in the cortical stores of Paramecium represent RyRs, or RyR-LPs.

\subsection{Mixed types of CRCs and common origin}

Let us now ask whether there may have been a common ancestor of $\mathrm{IP}_{3} \mathrm{Rs}$ and RyRs, considering the intermediate forms mentioned. This follows from presence/absence of an $\mathrm{InsP}_{3}$ binding domain and/or of RIH domain, variable aminoacid sequence of selectivity filter, etc., as shown in these molecules in Paramecium [44]. Remarkably, despite considerable difference in size between $\mathrm{IP}_{3} \mathrm{Rs}$ and RyRs in vertebrates, both vertebrate channel forms show a coherent allosteric gating [128]. Also the conserved structural architecture of the aminoterminal part suggests common precursor [129]. Further support comes from the recent insight - based on advanced algorithms applied to the evaluation of established trans-membrane proteins as indicated by Ladenburger and Plattner [44] - that in the carboxyterminal part six trans-membrane domains occur in both channel types, rather than only four in the RyR. This applies not only to ciliates [44], but is now propagated also for mammals $[130,131 a, b]$. Furthermore, the selectivity filter has previously been assumed to show a clear differentiation between the two channel types [132]: In mammals, the sequence GVGD has been assigned to $\mathrm{IP}_{3}$ Rs and GIGD to RyRs. In contrast, in Paramecium and other "lower" eukaryotes both channels can contain the GIGD or still other signatures [133]. All this is compatible with a common ancestor for both channel types and such forms show up in Paramecium's collection of $\mathrm{IP}_{3}$ Rs/RyR-LPs [44].

It has been suggested, however, that CRCs in protozoa would be due to vertical gene transfer [35]. Considering on the one hand the considerable number of $\mathrm{Ca}^{2+}$ regulating and of $\mathrm{Ca}^{2+}$ regulated proteins in protozoan cells (for ciliates, see [18]), and on the other hand the general and imperative requirement of $\mathrm{Ca}^{2+}$ for the regulation of vesicle trafficking already in early times of evolution (Section 1), one may consider this not very likely. Both types of CRCs may also occur in a variety of organisms where, up to recently, RyRs or RyRLPs have not been detected in broad scanning explorations [134] when they did not apply domain specific analysis. Particularly the pore domain with its filter region can be helpful for identification because this is rather well conserved and most crucial for specific channel function [133]. 
A

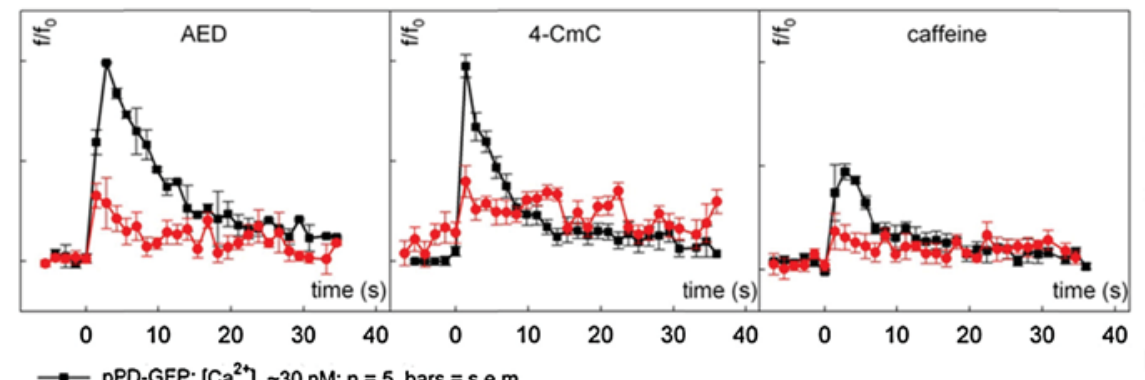

D

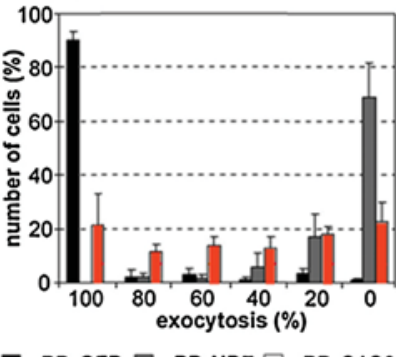

pPD-GFP $\square$ pPD-ND7 $\square$ pPD-C1C2<smiles>C1C2CC1C2</smiles>

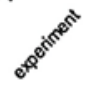

Fig. 4. Involvement of RyR-LPs in stimulated trichocyst exocytosis. (A-C) Fluorochrome analysis of $\mathrm{Ca}^{2+}$ signals generated by $\mathrm{AED}(\mathrm{A}), 4 \mathrm{CmC}(\mathrm{B})$ and caffeine $(\mathrm{C})$ at $\left[\mathrm{Ca}{ }^{2+}\right]_{0}$ shortly reduced to $\sim 0.03 \mu \mathrm{M}$, i.e. below the level at rest. Black curves are for normal cells, red curves for cells silenced in the RyR-LP of alveolar sacs. Note that in silenced cells the signal is clearly reduced. Bars = standard errors. (D) Evaluation of trichocyst exocytosis in normal wildtype cells (black bars) and in cells silenced in the RyR-LP of alveolar sacs (red bars). Cells were assigned to six groups, from 100 to $0 \%$ exocytosis (abscissa), with the percent activity indicated in the ordinate. The reduced activity in silenced cells (red columns) becomes, thus, evident. Only exocytosis-incompetent ND7 mutant cells, used for additional controls (grey columns), show more stringent reduction of exocytosis than silenced cells because the effect of the posttranscriptional silencing used is never all-or-none. (E) Carboxyterminal part of the RyR-LP, with two isoforms (PtCRC-IV-1a [erroneously labelled VI in the original work reproduced here] and PtCRC-IV-1b) showing that these channels are considerably shorter than their equivalents in rabbit (Oryctolagus cuniculus), OcRyR types 1-3. Moreover it shows coincident position of aminoacids $\mathrm{Q}$ and $\mathrm{K} / \mathrm{R}$ (yellow) at positions considered critical for $4 \mathrm{CmC}$ binding in mammals, as indicated in the text. From Ladenburger et al. [45].

Whenever analyses were not restricted to overall nucleotide similarity, similar CRCs could be detected also in some other protozoan species. In the flagellated protozoans, Trypanosoma brucei [135] and Trypanosoma cruzi [136], $\mathrm{IP}_{3} \mathrm{R}$ channels have thus been identified, complemented by thorough experimental work comparable to that with Paramecium. This included activation studies, intracellular localisation, knockdown experiments and functional analysis. Similar work would now be necessary also for all of the other para-/ohnologues of $\mathrm{IP}_{3} \mathrm{R} / \mathrm{Ry}$ R-type channels in Paramecium, altogether 34, grouped in 6 subfamilies [44]. Their selective arrangement in different compartments is presented in a parallel paper in this issue [30]. This multitude may be exceptional, yet all

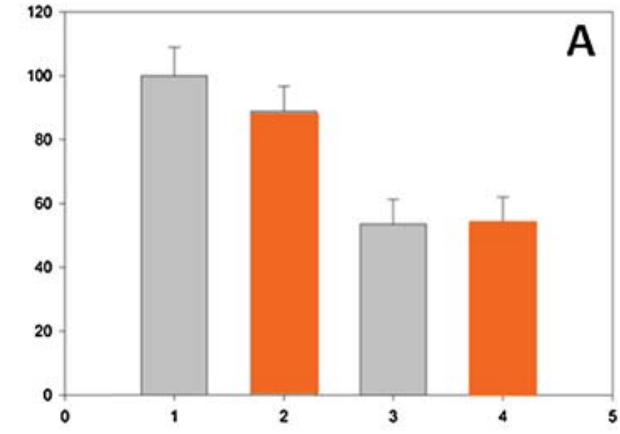

Ordinate: [Ca] found by EDX in alveolar sacs of double mutant. All data normalized (column $1=100 \%$ ); values $+/-$ s.e.m. columns: $1,2=$ unstimulated, $2,3=$ AED-stimulated $1,3=$ permissively $\left(25^{\circ} \mathrm{C}\right), 2,4=$ non-permissively $\left(35^{\circ} \mathrm{C}\right)$

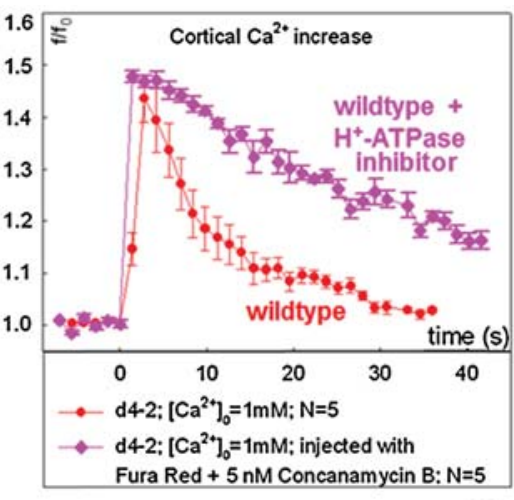

B

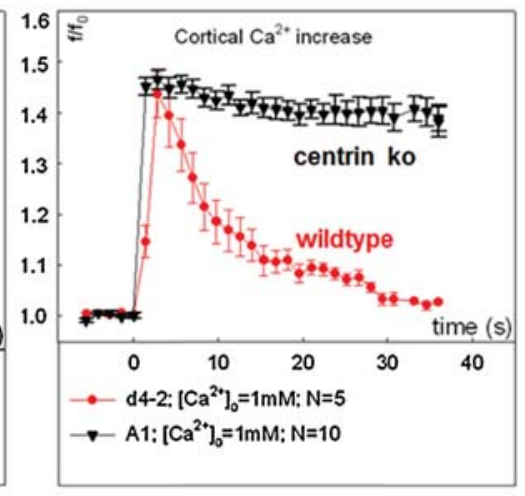

C

Fig. 5. Relevant aspects of signalling during stimulated trichocyst exocytosis. This includes SOCE for signalling (A) and $\mathrm{H}^{+}$-ATPase activity (B) as well as binding of $\mathrm{Ca}^{2+}$ to cortical centrin (C). (B, C) both serve for signal downregulation. (A) The release of $\mathrm{Ca}^{2+}$ from alveolar sacs was registered by evaluating CaK $\alpha$ signals by EDX at the electron microscope level. Wildtype cells (grey columns) and a double mutant devoid of $\mathrm{Ca}^{2+}$ influx (orange columns) were analysed. Columns 1,2 are resting cells, columns 2,3 are AED stimulated cells. The amount of $\mathrm{Ca}^{2+}$ released during stimulation is the same, with and without $\mathrm{Ca}^{2+}$ influx, respectively, thus excluding CICR and supporting SOCE. Bars are standard deviations. (B) After exocytosis stimulation by AED, cortical $\left[\mathrm{Ca}^{2+}\right]_{i}$ is downregulated considerably more rapidly in wildtype cells under normal conditions than after exposure to the $\mathrm{H}^{+}$-ATPase inhibitor, concanamycin B. From the occurrence of this pump in the contractile vacuole complex, its strong Ca ${ }^{2+}$ expulsion activity (see text) and inhibition by concanamycin B it is concluded that $\mathrm{Ca}^{2+}$ is sequestered by a secondary active antiport pathway. (C) Knock-out of cortical centrin-binding protein impedes the assembly of cortical centrin that is normally contained in the infraciliary lattice. Its elimination causes a big delay in the downregulation of cortical [Ca $\left.{ }^{2+}\right]_{i}$ after AED stimulation. (A) is from Mohamed et al. [62], (B) from Plattner et al. [52], (B) and (C) are from Refs. [52] and [19], respectively. 
(but one) are expressed. On the one hand diversification of these CRCs is evident, but on the other hand some forms probably serve for a kind of gene amplification.

Attempts toward identification of $\mathrm{IP}_{3} \mathrm{Rs}$ appear a particularly rewarding challenge, particularly in those protozoan species where $\mathrm{InsP}_{3}$ effects have been reported. This is the case, e.g. with Apicomplexan parasites; see contribution by Moreno [20]. Remarkably, for choanoflagellates Cai et al. ([137]) indicate the presence of $\mathrm{IP}_{3} \mathrm{Rs}$ in Monosiga and of RyRs in Salpingoeca. One may now expect from scrutiny either the occurrence of both channel types, and/or of an intermediate channel type in each of the two species.

\subsection{Are there other $\mathrm{Ca}^{2+}$ release channels and antiporters in Paramecium?}

NAADP (nicotinic acid adeninedinucleotidephosphate) is considered the activator of two-pore channels (TPC) that are widely distributed among organisms [138]; see contribution by Patel and Cai [139]. With Paramecium homogenates and under intracellular ionic conditions we determined a $K_{\mathrm{D}}$ of $3.5 \mathrm{nM}$ for NAADP binding and microinjected NAADP clearly caused a $\mathrm{Ca}^{2+}$-based response [19] which, however, was not further specified. We expect the occurrence of TPCs, but this still awaits experimental verification. This is in contrast to what is currently assumed for higher plants (Edel and Kudla [86]).

Gene sequences suggest the presence of a $\mathrm{Na}^{+} / \mathrm{Ca}^{2+}$ antiporter in Tetrahymena [140], but beyond this cursory note neither its localisation nor its function has been followed up. The occurrence of a $\mathrm{H}^{+} / \mathrm{Ca}^{2+}$ exchanger is very likely for the contractile vacuole complex because the organelle actively sequesters protons and releases $\mathrm{Ca}^{2+}$ not only into the outside medium, but also into the cytosol (see above) and, because no acidification of the organelle is recognized [141]. This strongly indicates exploitation of a $\mathrm{H}^{+}$gradient for the secondary active transport of $\mathrm{Ca}^{2+}$. Experiments with the $\mathrm{H}^{+}$ATPase inhibitor, concanamycin B, support this concept (Fig. 5B).

In Paramecium, one type of $\mathrm{Ca}^{2+}$ release channel, CRC-V-4, with a small $\mathrm{InsP}_{3}$-binding homology domain, is associated with parasomal sacs, the clathrin coated pits [44]. A light and electron microscope picture is presented in the accompanying paper [30]. This channel is a candidate for ill-defined channels with high conductance/low selectivity described by electrophysiologists [22].

\section{Conclusions}

One may now try to make a balance sheet of components pertinent to $\mathrm{Ca}^{2+}$ signalling in ciliates, specifically for Paramecium. The essential mechanisms (beyond cilia) are represented by experimental data shown in Fig. 5. Work with a mutant devoid of $\mathrm{Ca}^{2+}$ influx used for EDX analysis strongly supports the SOCE mechanism of signalling during stimulated exocytosis. Such rapid coupling of internal $\mathrm{Ca}^{2+}$ mobililsation and enforcement by strictly coupled $\mathrm{Ca}^{2+}$ influx is vital for surviving as it wards off very efficiently predator attacks [142]. Downregulation takes place very rapidly by $\mathrm{Ca}^{2+}$ binding to cortical centrin and in parallel by $\mathrm{Ca}^{2+}$ expulsion via the contractile vacuole complex. Cilia are essentially autonomous compartments with their own $\mathrm{Ca}^{2+}$ influx and downregulation system.

Paramecium is currently one of the best experimentally analysed unicellular model. Comparison of the two main lineages, uniand bikonts, reveals the following tendencies. (i) There are components shared by Paramecium, higher animals and higher plants. This includes CaM, centrin, PMCA, SERCA, copines and annexins. (ii) Components shared with animals are voltage-gated $\mathrm{Ca}^{2+}$ channels, dimeric calcineurin, $\mathrm{IP}_{3} \mathrm{Rs}$, RyR-LPs and possibly TPCs. (iii) Ciliates share CDPKs with plants which here dominate over
$\mathrm{Ca}^{2+} / \mathrm{CaM}$-activated protein kinases. Only subunit B of calcineurin is retained in plants. Finally there is some uncertainty about lumenal high capacity/low affinity CaBPs, cation exchangers and TPCs in Paramecium.

\section{Acknowledgment}

The author's work cited herein has been supported by the German Research Council.

\section{References}

[1] M. Simon, H. Plattner, Unicellular eukaryotes as models in cell and molecular biology: critical appraisal of their past and future value, Int. Rev. Cell Mol. Biol. 309 (2014) 141-198.

[2] A.-D. Wright, D.H. Lynn, Maximum ages of ciliate lineages estimated using a small subunit rRNA molecular clock: crown eukaryotes date back to the paleoproterozoic, Arch. Protistenkd. 148 (1997) 329-341.

[3] E.J. Douzéry, E.A. Snell, E. Bapteste, F. Delsuc, H. Philippe, The timing of eukaryotic evolution: does a relaxed molecular clock reconcile proteins and fossils? Proc. Natl. Acad. Sci. U. S. A. 101 (2004) 15386-15391.

[4] C. Berney, J. Pawlowski, A molecular time-scale for eukaryote evolution recalibrated with the continuous microfossil record, Proc. Biol. Sci. 273 (2006) 1867-1872.

[5] A.H. Knoll, Proterozoic and early Cambrian protists: evidence for accelerating evolutionary tempo, Proc. Natl. Acad. Sci. U. S. A. 91 (1994) 6743-6750.

[6] L.W. Parfrey, D.J. Lahr, A.H. Knoll, L.A. Katz, Estimating the timing of early eukaryotic diversification with multigene molecular clocks, Proc. Natl. Acad. Sci. U. S. A. 108 (2011) 13624-13629.

[7] J.B. Dacks, M.C. Field, Evolution of the eukaryotic membrane-trafficking system: origin, tempo and mode, J. Cell Sci. 120 (2007) 2977-2985.

[8] M. Elias, Patterns and processes in the evolution of the eukaryotic endomembrane system, Mol. Membr. Biol. 27 (2010) 469-489.

[9] P. Forterre, The common ancestor of archaea and eukarya was not an archaeon, Archaea 2013 (2013), http://dx.doi.org/10.1155/2013/372396.

[10] T.H. Kloepper, C.N. Kienle, D. Fasshauer, SNAREing the basis of multicellularity: consequences of protein family expansion during evolution, Mol. Biol. Evol. 25 (2008) 2055-2068.

[11] H. Plattner, How to design a highly organized cell: an unexpectedly high number of widely diversified SNARE proteins positioned at strategic sites in the ciliate, Paramecium tetraurelia, Protist 161 (2010) 497-516.

[12] L.J. Bright, N. Kambesis, S.B. Nelson, B. Jeong, A.P. Turkewitz, Comprehensive analysis reveals dynamic and evolutionary plasticity of Rab GTPases and membrane traffic in Tetrahymena thermophila, PLoS Genet. 6 (2010) e1001155.

[13] A.M. Rojas, G. Fuentes, A. Rausell, A. Valencia, The Ras protein superfamily: evolutionary tree and role of conserved amino acids, J. Cell Biol. 196 (2012) 189-201.

[14] H. Plattner, A. Verkhratsky, The ancient roots of calcium signalling evolutionary tree, Cell Calcium 57 (2015) 123-132.

[15] D.C. Domínguez, M. Guragain, M. Patrauchan, Calcium binding proteins and calcium signalling in prokaryotes, Cell Calcium 57 (2015) 151-165.

[16] T. Cavalier-Smith, Protist phylogeny and the high-level classification of protozoa, Eur. J. Protistol. 39 (2003) 338-348.

[17] F. Burki, J. Pawlowski, Monophyly of Rhizaria and multigene phylogeny of unicellular bikonts, Mol. Biol. Evol. 23 (2006) 1922-1930.

[18] H. Plattner, Calcium regulation in the protozoan model, Paramecium tetraurelia, J. Eukaryot. Microbiol. 61 (2014) 95-114.

[19] H. Plattner, I.M. Sehring, I.K. Mohamed, K. Miranda, W. De Souza, R. Billington, A. Genazzani, E.M. Ladenburger, Calcium signalling in closely related protozoan groups (Alveolata): non-parasitic ciliates (Paramecium, Tetrahymena) vs. parasitic Apicomplexa (Plasmodium, Toxoplasma), Cell Calcium 51 (2012) 351-382.

[20] S. Moreno, The calcium toolkit of the apicomplexan parasites Toxoplasma gondii and Plasmodium spp., Cell Calcium 57 (2015) 186-193.

[21] R.E. Ricklefs, D.C. Outlaw, A molecular clock for malaria parasites, Science 329 (2010) 226-229.

[22] H. Machemer, Electrophysiology, in: H.-D. Görtz (Ed.), Paramecium, SpringerVerlag, Berlin/Heide berg, 1988, pp. 185-215.

[23] H. Machemer, Motor control of cilia, in: H.-D. Görtz (Ed.), Paramecium, Springer-Verlag, Berlin/Heidelberg, 1988, pp. 216-235.

[24] Y. Saimi, C. Kung, Calmodulin as an ion channel subunit, Annu. Rev. Physiol. 64 (2002) 289-311.

[25] C. Kung, B. Martinac, S. Sukharev, Mechanosensitive channels in microbes, Annu. Rev. Microbiol. 64 (2010) 313-329.

[26] J. Beisson, Preformed cell structure and cell heredity, Prion 2 (2008) 1-8.

[27] A. Aubusson-Fleury, M. Lemullois, N.G. de Loubresse, C. Laligne, J. Cohen, O. Rosnet, M. Jerka-Dziadosz, J. Beisson, F. Koll, The conserved centrosomal protein FOR20 is required for assembly of the transition zone and basal body docking at the cell surface, J. Cell Sci. 125 (2012) 4395-4404.

[28] G. Knoll, C. Braun, H. Plattner, Quenched flow analysis of exocytosis in Paramecium cells: time course, changes in membrane structure, and calcium 
requirements revealed after rapid mixing and rapid freezing of intact cells, J. Cell Biol. 113 (1991) 1295-1304.

[29] H. Plattner, J. Hentschel, Sub-second cellular dynamics: time-resolved electron microscopy and functional correlation, Int. Rev. Cytol. 255 (2006) 133-176.

[30] H. Plattner, Calcium signalling in the ciliated protozoan model, Paramecium: strict signal localisation by epigenetically controlled positioning of different $\mathrm{Ca}^{2+}$-release channels, Cell Calcium 57 (2015) 203-213.

[31] J.M. Aury, O. Jaillon, L. Duret, B. Noel, C. Jubin, B.M. Porcel, B. Segurens, V. Daubin, V. Anthouard, N. Aiach, O. Arnaiz, A. Billaut, J. Beisson, I. Blanc, K. Bouhouche, F. Camara, S. Duharcourt, R. Guigo, D. Gogendeau, M. Katinka, A.M. Keller, R. Kissmehl, C. Klotz, F. Koll, A. Le Mouel, G. Lepere, S. Malinsky, M. Nowacki, J.K. Nowak, H. Plattner, J. Poulain, F. Ruiz, V. Serrano, M. Zagulski, P. Dessen, M. Bétermier, J. Weissenbach, C. Scarpelli, V. Schachter, L. Sperling, E. Meyer, J. Cohen, P. Wincker, Global trends of whole-genome duplications revealed by the ciliate Paramecium tetraurelia, Nature 444 (2006) 171-178.

[32] J.A. Eisen, R.S. Coyne, M. Wu, D. Wu, M. Thiagarajan, J.R. Wortman, J.H. Badger, Q. Ren, P. Amedeo, K.M. Jones, L.J. Tallon, A.L. Delcher, S.L. Salzberg, J.C. Silva, B.J. Haas, W.H. Majoros, M. Farzad, J.M. Carlton, R.K. Smith Jr., J. Garg, R.E. Pearlman, K.M. Karrer, L. Sun, G. Manning, N.C. Elde, A.P. Turkewitz, D.J. Asai, D.E. Wilkes, Y. Wang, H. Cai, K. Collins, B.A. Stewart, S.R. Lee, K. Wilamowska, Z. Weinberg, W.L. Ruzzo, D. Wloga, J. Gaertig, J. Frankel, C.C. Tsao, M.A. Gorovsky, P.J. Keeling, R.F. Waller, N.J. Patron, J.M. Cherry, N.A. Stover, C.J. Krieger, C. Del Toro, H.F. Ryder, S.C. Williamson, R.A. Barbeau, E.P. Hamilton, E. Orias, Macronuclear genome sequence of the ciliate Tetrahymena thermophila, a model eukaryote, PLoS Biol. 4 (2006) e286.

[33] O. Arnaiz, J.F. Goût, M. Bétermier, K. Bouhouche, J. Cohen, L. Duret, A. Kapusta, E. Meyer, L. Sperling, Gene expression in a paleopolyploid: a transcriptome resource for the ciliate Paramecium tetraurelia, BMC Genom. 11 (2010) 547.

[34] D. Fraga, I.M. Sehring, R. Kissmehl, M. Reiss, R. Gaines, R. Hinrichsen, H. Plattner, Protein phosphatase 2B (PP2B, calcineurin) in Paramecium: partial characterization reveals that two members of the unusually large catalytic subunit family have distinct roles in calcium-dependent processes, Eukaryot. Cell 9 (2010) 1049-1063.

[35] J.J. Mackrill, Ryanodine receptor calcium release channels: an evolutionary perspective, Adv. Exp. Med. Biol. 740 (2012) 159-182.

[36] C. Erxleben, H. Plattner, $\mathrm{Ca}^{2+}$ release from subplasmalemmal stores as a primary event during exocytosis in Paramecium cells, J. Cell Biol. 127 (1994) 935-945.

[37] C. Erxleben, N. Klauke, M. Flötenmeyer, M.P. Blanchard, C. Braun, H. Plattner, Microdomain $\mathrm{Ca}^{2+}$ activation during exocytosis in Paramecium cells. Superposition of local subplasmalemmal calcium store activation by local $\mathrm{Ca}^{2+}$ influx, J. Cell Biol. 136 (1997) 597-607.

[38] N. Klauke, H. Plattner, Imaging of $\mathrm{Ca}^{2+}$ transients induced in Paramecium cells by a polyamine secretagogue, J. Cell Sci. 110 (1997) 975-983.

[39] N. Klauke, M. Blanchard, H. Plattner, Polyamine triggering of exocytosis in Paramecium involves an extracellular $\mathrm{Ca}^{2+} /($ polyvalent cation)-sensing receptor, subplasmalemmal Ca-store mobilization and store-operated $\mathrm{Ca}^{2+}$ influx via unspecific cation channels, J. Membr. Biol. 174 (2000) 141-156.

[40] M. Hardt, H. Plattner, Sub-second quenched-flow/X-ray microanalysis shows rapid $\mathrm{Ca}^{2+}$ mobilization from cortical stores paralleled by $\mathrm{Ca}^{2+}$ influx during synchronous exocytosis in Paramecium cells, Eur. J. Cell Biol. 79 (2000) 642-652.

[41] M.R. Husser, M. Hardt, M.P. Blanchard, J. Hentschel, N. Klauke, H. Plattner, One-way calcium spill-over during signal transduction in Paramecium cells: from the cell cortex into cilia, but not in the reverse direction, Cell Calcium 36 (2004) 349-358.

[42] G. Knoll, A. Grässle, C. Braun, W. Probst, B. Höhne-Zell, H. Plattner, A calcium influx is neither strictly associated with nor necessary for exocytotic membrane fusion in Paramecium cells, Cell Calcium 14 (1993) 173-183.

[43] H. Plattner, Membrane trafficking in protozoa: SNARE proteins, $\mathrm{H}^{+}$-ATPase, actin, and other key players in ciliates, Int. Rev. Cell Mol. Biol. 280 (2010) 79-184.

[44] E.M. Ladenburger, H. Plattner, Calcium-release channels in Paramecium. Genomic expansion, differential positioning and partial transcriptional elimination, PLoS ONE 6 (2011) e27111.

[45] E.M. Ladenburger, I.M. Sehring, I. Korn, H. Plattner, Novel types of $\mathrm{Ca}^{2+}$ release channels participate in the secretory cycle of Paramecium cells, Mol. Cell. Biol. 29 (2009) 3605-3622.

[46] E.M. Ladenburger, I. Korn, N. Kasielke, T. Wassmer, H. Plattner, An Ins $(1,4,5) \mathrm{P}_{3}$ receptor in Paramecium is associated with the osmoregulatory system, J. Cell Sci. 119 (2006) 3705-3717.

[47] J.L. Browning, D.L. Nelson, Biochemical studies of the excitable membrane of Paramecium aurelia. I. ${ }^{45} \mathrm{Ca}^{2+}$ fluxes across resting and excited membrane, Biochim. Biophys. Acta 448 (1976) 338-351.

[48] D. Kerboeuf, J. Cohen, A Ca ${ }^{2+}$ influx associated with exocytosis is specifically abolished in a Paramecium exocytotic mutant, J. Cell Biol. 111 (1990) 2527-2535.

[49] M.V. Wright, J.L. Van Houten, Characterization of a putative $\mathrm{Ca}^{2+}$-transporting $\mathrm{Ca}^{2+}$-ATPase in the pellicles of Paramecium tetraurelia, Biochim. Biophys. Acta 1029 (1990) 241-251.

[50] N.L. Elwess, J.L. Van Houten, Cloning molecular analysis of the plasma membrane $\mathrm{Ca}^{2+}$-ATPase gene in Paramecium tetraurelia, J. Eukaryot. Microbiol. 44 (1997) 250-257

[51] K. Hauser, N. Pavlovic, R. Kissmehl, H. Plattner, Molecular characterization of a sarco(endo)plasmic reticulum $\mathrm{Ca}^{2+}$-ATPase gene from Paramecium tetraurelia and localization of its gene product to sub-plasmalemmal calcium stores, Biochem. J. 334 (1998) 31-38

[52] H. Plattner, I.M. Sehring, C. Schilde, E.M. Ladenburger, Pharmacology of ciliated protozoa - drug (in)sensitivity and experimental drug (ab)use, Int. Rev. Cell Mol. Biol. 273 (2009) 163-218.

[53] K. Hauser, N. Pavlovic, N. Klauke, D. Geissinger, H. Plattner, Green fluorescent protein-tagged sarco(endo)plasmic reticulum $\mathrm{Ca}^{2+}$-ATPase overexpression in Paramecium cells: isoforms, subcellular localization, biogenesis of cortical calcium stores and functional aspects, Mol. Microbiol. 37 (2000) 773-787.

[54] H. Plattner, N. Klauke, Calcium in ciliated protozoa: sources, regulation, and calcium-regulated cell functions, Int. Rev. Cytol. 201 (2001) 115-208.

[55] I. Mohamed, M. Husser, I. Sehring, J. Hentschel, C. Hentschel, H. Plattner, Refilling of cortical calcium stores in Paramecium cells: in situ analysis in correlation with store-operated calcium influx, Cell Calcium 34 (2003) 87-96.

[56] R. Lopreiato, M. Giacomello, E. Carafoli, The plasma membrane calcium pump: new ways to look at an old enzyme, J. Biol. Chem. 289 (2014) 10261-10268.

[57] C. Stock, H.K. GrØnlien, R.D. Allen, The ionic composition of the contractile vacuole fluid of Paramecium mirrors ion transport across the plasma membrane, Eur. J. Cell Biol. 81 (2002) 505-515.

[58] A.K. Fok, M.S. Aihara, M. Ishida, K.V. Nolta, T.L. Steck, R.D. Allen, The pegs on the decorated tubules of the contractile vacuole complex of Paramecium are proton pumps, J. Cell Sci. 108 (1995) 3163-3170.

[59] T. Wassmer, M. Froissard, H. Plattner, R. Kissmehl, J. Cohen, The vacuolar proton-ATPase plays a major role in several membrane-bounded organelles in Paramecium, J. Cell Sci. 118 (2005) 2813-2825.

[60] T. Wassmer, R. Kissmehl, J. Cohen, H. Plattner, Seventeen a-subunit isoforms of Paramecium V-ATPase provide high specialization in localization and function, Mol. Biol. Cell 17 (2006) 917-930.

[61] N. Klauke, H. Plattner, Caffeine-induced $\mathrm{Ca}^{2+}$ transients and exocytosis in Paramecium cells. A correlated $\mathrm{Ca}^{2+}$ imaging and quenched-flow/freezefracture analysis, J. Membr. Biol. 161 (1998) 65-81.

[62] I. Mohamed, N. Klauke, J. Hentschel, J. Cohen, H. Plattner, Functional and fluorochrome analysis of an exocytotic mutant yields evidence of store-operated $\mathrm{Ca}^{2+}$ influx in Paramecium, J. Membr. Biol. 187 (2002) 1-14

[63] I.M. Sehring, C. Klotz, J. Beisson, H. Plattner, Rapid downregulation of the $\mathrm{Ca}^{2+}$ signal after exocytosis stimulation in Paramecium cells: essential role of a centrin-rich filamentous cortical network, the infraciliary lattice, Cell Calcium 45 (2009) 89-97.

[64] A.W. Henkel, W. Almers, Fast steps in exocytosis and endocytosis studied by capacitance measurements in endocrine cells, Curr. Opin. Neurobiol. 6 (1996) 350-357.

[65] H. Plattner, C. Braun, J. Hentschel, Facilitation of membrane fusion during exocytosis and exocytosis-coupled endocytosis and acceleration of "ghost" detachment in Paramecium by extracellular calcium. A quenchedflow/freeze-fracture analysis, J. Membr. Biol. 158 (1997) 197-208.

[66] M.D. Bootman, K.W. Young, J.M. Young, R.B. Moreton, M.J. Berridge, Extracellular calcium concentration controls the frequency of intracellular calcium spiking independently of inositol 1,4,5-trisphosphate production in HeLa cells, Biochem. J. 314 (1996) 347-354.

[67] C. Li, B. Ullrich, J.Z.Zhang, R.G. Anderson, N. Brose, T.C. Südhof, $\mathrm{Ca}^{2+}$-dependent and-independent activities of neural and non-neural synaptotagmins, Nature 375 (1995) 594-599.

[68] M. Midorikawa, Y. Okamoto, T. Sakaba, Developmental changes in $\mathrm{Ca}^{2+}$ channel subtypes regulating endocytosis at the calyx of Held, J. Physiol. 592 (2014) 3495-3510.

[69] R. Eckert, Bioelectric control of ciliary activity, Science 176 (1972) 473-481.

[70] D. Oertel, S.J. Schein, C. Kung, Separation of membrane currents using a Paramecium mutant, Nature 268 (1977) 120-124.

[71] K.P. Hoeflich, M. Ikura, Calmodulin in action: diversity in target recognition and activation mechanisms, Cell 108 (2002) 739-742.

[72] D. Gogendeau, C. Klotz O Arnaiz A. Malinowska, M. Dadlez N.G de Loubresse, F. Ruiz, F. Koll, J. Beisson, Functional diversification of centrins and cell morphological complexity, J. Cell Sci. 121 (2008) 65-74.

[73] K. Kim, M. Son, J.B. Peterson, D.L. Nelson, $\mathrm{Ca}^{2+}$-binding proteins of cilia and infraciliary lattice of Paramecium tetraurelia: their phosphorylation by purified endogenous $\mathrm{Ca}^{2+}$-dependent protein kinases, J. Cell Sci. 115 (2002) 1973-1984.

[74] E.R. Chapman, Synaptotagmin: a $\mathrm{Ca}^{2+}$ sensor that triggers exocytosis? Nat. Rev. Mol. Cell Biol. 3 (2002) 498-508.

[75] M. Momayezi, H. Kersken, U. Gras, J. Vilmart-Seuwen, H. Plattner, Calmodulin in Paramecium tetraurelia: localization from the in vivo to the ultrastructural level, J. Histochem. Cytochem. 34 (1986) 1621-1638.

[76] A.K. Fok, M.S. Aihara, M. Ishida, R.D. Allen, Calmodulin localization and its effects on endocytic and phagocytic membrane trafficking in Paramecium multimicronucleatdum, J. Eukaryot. Microbiol. 55 (2008) 481-491.

[77] H. Plattner, The contractile vacuole complex of protists - new cues to function and biogenesis, Crit. Rev. Microbiol. (2013), http://dx.doi.org/10.3109/1040841X. 2013.821650.

[78] K. Gonda, K. Oami, M. Takahashi, Centrin controls the activity of the ciliary reversal-coupled voltage-gated $\mathrm{Ca}^{2+}$ channels $\mathrm{Ca}^{2+}$-dependently, Biochem. Biophys. Res. Commun. 362 (2007) 170-176.

[79] J.E. Schultz, S. Klumpp, Cyclic nucleotides and calcium signalling in Paramecium, Adv. Sec. Mess. Phosphoprot. Res. 27 (1993) 25-46.

[80] K.S. Ann, D.L. Nelson, Protein substrates for cGMP-dependent protein phosphorylation in cilia of wild type and atalanta mutants of Paramecium, Cell Motil. Cytoskel. 30 (1995) 252-260. 
[81] J.U. Linder, P. Engel, A. Reimer, T. Krüger, H. Plattner, A. Schultz, J.E. Schultz, Guanylyl cyclases with the topology of mammalian adenylyl cyclases and an N-terminal P-type ATPase-like domain in Paramecium, Tetrahymena and Plasmodium, EMBO J. 18 (1999) 4222-4232.

[82] D. Kerboeuf, A. Le Berre, J.C. Dedieu, J. Cohen, Calmodulin is essential for assembling links necessary for exocytotic membrane fusion in Paramecium, EMBO J. 12 (1993) 3385-3390.

[83] S. Quetglas, C. Iborra, N. Sasakawa, L. De Haro, K. Kumakura, K. Sato, C. Leveque, M. Seagar, Calmodulin and lipid binding to synaptobrevin regulates calciumdependent exocytosis, EMBO J. 21 (2002) 3970-3979.

[84] H.J. Junge, J.S. Rhee, O. Jahn, F. Varoqueaux, J. Spiess, M.N. Waxham, C. Rosenmund, N. Brose, Calmodulin and Munc13 form a Ca ${ }^{2+}$ sensor/effector complex that controls short-term synaptic plasticity, Cell 118 (2004) 389-401.

[85] G.R. Valmonte, K. Arthur, C.M. Higgins, R.M. MacDiarmid, Calcium-dependen protein kinases in plants: evolution, expression and function, Plant Cell Physiol. 55 (2014) 551-569.

[86] K.H. Edel, J. Kudla, Increasing complexity and versatility: how the calcium signalling toolkit was shaped during plant land colonization, Cell Calcium 57 (2015) 231-246.

[87] D. Vetter, R. Kissmehl, T. Treptau, K. Hauser, J. Kellermann, H. Plattner, Molecular identification of a calcium-inhibited catalytic subunit of casein kinase type 2 from Paramecium tetraurelia, Eukaryot. Cell 2 (2003) $1220-1233$.

[88] R. Kissmehl, T. Treptau, B. Kottwitz, H. Plattner, Occurrence of a paranitrophenyl phosphate-phosphatase with calcineurin-like characteristics in Paramecium tetraurelia, Arch. Biochem. Biophys. 344 (1997) 260-270.

[89] H. Plattner, R. Kissmehl, Dense-core secretory vesicle docking and exocytotic membrane fusion in Paramecium cells, Biochim. Biophys. Acta 1641 (2003) 183-193.

[90] T. Vonderfecht, A.J. Stemm-Wolf, M. Hendershott, T.H. Giddings Jr., J.B. Meehl, M. Winey, The two domains of centrin have distinct basal body functions in Tetrahymena, Mol. Biol. Cell 22 (2011) 2221-2234.

[91] S. Nair, C. Guerra, P. Satir, A Sec7-related protein in Paramecium, FASEB J. 13 (1999) 1249-1257.

[92] J. Laoukili, E. Perret, S. Middendorp, O. Houcine, C. Guennou, F. Marano, M. Bornens, F. Tournier, Differential expression and cellular distribution of centrin isoforms during human ciliated cell differentiation in vitro, J. Cell Sci. 113 (2000) 1355-1364

[93] S. Martens, H.T. McMahon, Mechanisms of membrane fusion: disparate players and common principles, Nat. Rev. Mol. Cell Biol. 9 (2008) 543-556.

[94] Z.P. Pang, T.C. Südhof, Cell biology of $\mathrm{Ca}^{2+}$-triggered exocytosis, Curr. Opin. Cell Biol. 22 (2010) 496-505.

[95] C.E. Creutz, J.L. Tomsig, S.L. Snyder, M.C. Gautier, F. Skouri, J. Beisson, J. Cohen, The copines, a novel class of C2 domain-containing, calcium-dependent, phospholipid-binding proteins conserved from Paramecium to humans, J. Biol. Chem. 273 (1998) 1393-1402.

[96] V. Gerke, C.E. Creutz, S.E. Moss, Annexins: linking $\mathrm{Ca}^{2+}$ signalling to membrane dynamics, Nat. Rev. Mol. Cell Biol. 6 (2005) 449-461.

[97] M. Knochel, R. Kissmehl, J.D. Wissmann, M. Momayezi, J. Hentschel, H. Plattner, R.D. Burgoyne, Annexins in Paramecium cells. Involvement in sitespecific positioning of secretory organelles, Histochem. Cell Biol. 105 (1996) 269-281.

[98] J.L. Tomsig, C.E. Creutz, Copines: a ubiquitous family of $\mathrm{Ca}^{2+}$-dependent phospholipid-binding proteins, Cell. Mol. Life Sci. 59 (2002) 1467-1477.

[99] Y. Li, M. Gou, Q. Sun, J. Hua, Requirement of calcium binding, myristoylation, and protein-protein interaction for the copine BON1 function in Arabidopsis, J. Biol. Chem. 285 (2010) 29884-29891.

[100] D. Konopka-Postupolska, G. Clark, A. Hofmann, Structure, function and membrane interactions of plant annexins: an update, Plant Sci. 181 (2011) $230-241$.

[101] I.B. Levitan, It is calmodulin after all! Mediator of the calcium modulation of multiple ion channels, Neuron 22 (1999) 645-648.

[102] H. Plattner, A. Habermann, R. Kissmehl, N. Klauke, I. Majoul, H.D. Söling, Differential distribution of calcium stores in Paramecium cells. Occurrence of subplasmalemmal store with a calsequestrin-like protein, Eur. J. Cell Biol. 72 (1997) 297-306.

[103] J.H. Cho, Y.S. Oh, K.W. Park, J. Yu, K.Y. Choi, J.Y. Shin, D.H. Kim, W.J. Park, T. Hamada, H. Kagawa, E.B. Maryon, J. Bandyopadhyay, J. Ahnn, Calsequestrin, a calcium sequestering protein localized at the sarcoplasmic reticulum, is not essential for body-wall muscle function in Caenorhabditis elegans, J. Cell Sci. 113 (2000) 3947-3958.

[104] M. Bilinski, H. Plattner, H. Matt, Secretory protein decondensation as a distinct, $\mathrm{Ca}^{2+}$-mediated event during the final steps of exocytosis in Paramecium cells, J. Cell Biol. 88 (1981) 179-188.

[105] N. Klauke, R. Kissmehl, H. Plattner, N. Haga, T. Watanabe, An exocytotic mutan of Paramecium caudatum: membrane fusion without secretory contents release, Cell Calcium 23 (1998) 349-360.

[106] R. Kissmehl, M. Froissard, H. Plattner, M. Momayezi, J. Cohen, NSF regulates membrane traffic along multiple pathways in Paramecium, J. Cell Sci. 115 (2002) 3935-3946.

[107] R.D. Allen, A.K. Fok, Membrane trafficking and processing in Paramecium, Int. Rev. Cytol. 198 (2000) 277-318.

108] R.D. Allen, Y. Naitoh, Osmoregulation and contractile vacuoles of protozoa, Int. Rev. Cytol. 215 (2002) 379-394
[109] J.E. Grover, A.F. Rope, E.S. Kaneshiro, The occurrence of biogenic calcian struvite, (Mg,Ca) $\mathrm{NH}_{4} \mathrm{PO}_{4} \cdot 6 \mathrm{H}_{2} \mathrm{O}$, as intracellular crystals in Paramecium, J. Eukaryot. Microbiol. 44 (1997) 366-373.

[110] A.G. Bick, S.E. Calvo, V.K. Mootha, Evolutionary diversity of the mitochondrial calcium uniporter, Science 336 (2012) 886.

[111] Y. Sancak, A.L. Markhard, T. Kitami, E. Kovacs-Bogdan, K.J. Kamer, N.D. Udeshi, S.A. Carr, D. Chaudhuri, D.E. Clapham, A.A. Li, S.E. Calvo, O. Goldberger, V.K. Mootha, EMRE is an essential component of the mitochondrial calcium uniporter complex, Science 342 (2013) 1379-1382.

[112] R.S. Balaban, The role of $\mathrm{Ca}^{2+}$ signalling in the coordination of mitochondrial ATP production with cardiac work, Biochim. Biophys. Acta 1787 (2009) 1334-1341.

[113] T. Fenchel, Respiration in heterotrophic unicellular eukaryotic organisms, Protist 165 (2014) 485-492.

[114] H. Machemer, A. Ogura, Ionic conductances of membranes in ciliated and deciliated Paramecium, J. Physiol. 296 (1979) 49-60.

[115] A. Ogura, H. Machemer, Distribution of mechanoreceptor channels in the Paramecium surface-membrane, J. Comp. Physiol. C 135 (1980) 233-242.

[116] R. Eckert, P. Brehm, Ionic mechanisms of excitation in Paramecium, Annu. Rev. Biophys. Bioeng. 8 (1979) 353-383

[117] P. Brehm, R. Eckert, Calcium entry leads to inactivation of calcium channel in Paramecium, Science 202 (1978) 1203-1206.

[118] R.R. Preston, Y. Saimi, C. Kung, Calcium current activated upon hyperpolarization of Paramecium tetraurelia, J. Gen. Physiol. 100 (1992) 233-251.

[119] C. Cárdenas, R.A. Miller, I. Smith, T. Bui, J. Molgó, M. Müller, H. Vais, K.H. Cheung, J. Yang, I. Parker, C.B. Thompson, M.J. Birnbaum, K.R. Hallows, J.K. Foskett, Essential regulation of cell bioenergetics by constitutive InsP $\mathrm{P}_{3}$ receptor $\mathrm{Ca}^{2+}$-transfer to mitochondria, Cell 142 (2010) 270-283.

[120] T. Tominaga, R. Allen, Electrophysiology of the in situ contractile vacuole complex of Paramecium reveals its membrane dynamics and electrogenic site during osmoregulatory activity, J. Exp. Biol. 201 (1998) 451-460.

[121] H.K. Grønlien, C. Stock, M.S. Aihara, R.D. Allen, Y. Naitoh, Relationship between the membrane potential of the contractile vacuole complex and its osmoregulatory activity in Paramecium multimicronucleatum, J. Exp. Biol. 205 (2002) 3261-3270.

122] H. Plattner, R. Stürzl, H. Matt, Synchronous exocytosis in Paramecium cells. IV. Polyamino compounds as potent trigger agents for repeatable triggerredocking cycles, Eur. J. Cell Biol. 36 (1985) 32-37.

[123] H.C. Lee, Cyclic ADP-ribose and nicotinic acid adenine dinucleotide phosphate (NAADP) as messengers for calcium mobilization, J. Biol. Chem. 287 (2012) 31633-31640.

[124] J.D. Fessenden, W. Feng, I.N. Pessah, P.D. Allen, Amino acid residues Gln4020 and Lys 4021 of the ryanodine receptor type 1 are required for activation by 4-chloro-m-cresol, J. Biol. Chem. 281 (2006) 21022-21031.

[125] M. Wehner, H. Rueffert, F. Koenig, C.D. Meinecke, D. Olthoff, The Ile2453Thr mutation in the ryanodine receptor gene 1 is associated with facilitated calcium release from sarcoplasmic reticulum by 4-chloro-m-cresol in human myotubes, Cell Calcium 34 (2003) 163-168.

[126] C.W. Taylor, I.C. Marshall, Calcium and inositol 1,4,5-trisphosphate receptors: a complex relationship, Trends Biochem. Sci. 17 (1992) 403-407.

[127] X.L. Zhou, C.W. Chan, Y. Saimi, C. Kung, Functional reconstitution of ion channels from Paramecium cortex into artificial liposomes, J. Membr. Biol. 144 (1995) 199-208.

[128] K. Hamada, K. Mikoshiba, Revisiting channel allostery: a coherent mechanism in $\mathrm{IP}_{3}$ and ryanodine receptors, Sci. Signal. 5 (2012) pe24.

[129] F.J. Amador, P.B. Stathopulos, M. Enomoto, M. Ikura, Ryanodine receptor calcium release channels: lessons from structure-function studies, FEBS J. 280 (2013) 5456-5470.

[130] S. Ramachandran, A. Chakraborty, L. Xu, Y. Mei, M. Samsó, N.V. Dokholyan, G. Meissner, Structural determinants of skeletal muscle ryanodine receptor gating, J. Biol. Chem. 288 (2013) 6154-6165.

[131] (a) A.C. Gomez, N. Yamaguchi, Two regions of the ryanodine receptor calcium channel are involved in $\mathrm{Ca}^{2+}$-dependent inactivation, Biochemistry 53 (2014) 1373-1379;

(b) R. Zalk, O.B. Clark, A. des Georges, R.A. Grassucci, S. Reiken, F. Mancia, W.A. Hendickson, J. Frank, A.R. Marks, Structure of a mammalian ryanodine receptor, Nature (2014), http://dx.doi.org/10.1038/nature13950.

[132] D.F. Boehning, Molecular architecture of the inositol 1,4,5-trisphosphate receptor pore, Curr. Top. Membr. 66C (2010) 191-207.

[133] H. Plattner, A. Verkhratsky, $\mathrm{Ca}^{2+}$ signalling early in evolution - all but primitive, J. Cell Sci. 126 (2013) 2141-2150.

[134] S.R. Collins, T. Meyer, Evolutionary origins of STIM1 and STIM2 within ancient $\mathrm{Ca}^{2+}$ signalling systems, Trends Cell Biol. 21 (2011) 202-211.

[135] G. Huang PJ. Bartlett, A.P. Thomas, S.N. Moreno, R. Docampo, Acidocalcisomes of Trypanosoma brucei have an inositol 1,4,5-trisphosphate receptor that is required for growth and infectivity, Proc. Natl. Acad. Sci. U. S. A. 110 (2013) 1887-1892.

[136] M. Hashimoto, M. Enomoto, J. Morales, N. Kurebayashi, T. Sakurai, T. Hashimoto, T. Nara, K. Mikoshiba, Inositol 1,4,5-trisphosphate receptor regulates replication, differentiation, infectivity and virulence of the parasitic protist Trypanosoma cruzi, Mol. Microbiol. 87 (2013) 1133-1150.

[137] X. Cai, X. Wang, S. Patel, D.E. Clapham, Insights into the early evolution of animal calcium signalling machinery: a unicellular point of view, Cell Calcium 57 (2015) 166-173. 
[138] A. Galione, A.M. Evans, J. Ma, J. Parrington, A. Arredouani, X. Cheng, M.X. Zhu, The acid test: the discovery of two-pore channels (TPCs) as NAADP-gated endolysosomal $\mathrm{Ca}^{2+}$ release channels, Eur. J. Physiol. 458 (2009) 869-876.

[139] Patel S., Cai X., Evolution of acid $\mathrm{Ca}^{2+}$ stores and their resident $\mathrm{Ca}^{2+}$-permeable channels, Cell Calcium 57 (2015) 222-230.

[140] A. Haddad, G.R. Bowman, A.P. Turkewitz, New class of cargo protein in Tetrahymena thermophila dense core secretory granules, Eukaryot. Cell 1 (2002) 583-593.
[141] T. Wassmer, I.M. Sehring, R. Kissmehl, H. Plattner, The V-ATPase in Paramecium: functional specialization by multiple gene isoforms, Eur. J. Physiol. 457 (2009) 599-607.

[142] G. Knoll, B. Haacke-Bell, H. Plattner, Local trichocyst exocytosis provides an efficient escape mechanism for Paramecium cells, Eur. J. Protistol. 27 (1991) 381-385. 